Portland State University

PDXScholar

8-13-2020

\title{
A Land of Poets and Warriors: the Connection Between Warrior Culture and Bardic Culture in Medieval Wales c. 1066-1283
}

Sarah Lynn Alderson

Portland State University

Follow this and additional works at: https://pdxscholar.library.pdx.edu/open_access_etds

Part of the Medieval History Commons, Medieval Studies Commons, and the Military History Commons

Let us know how access to this document benefits you.

\section{Recommended Citation}

Alderson, Sarah Lynn, "A Land of Poets and Warriors: the Connection Between Warrior Culture and Bardic Culture in Medieval Wales c. 1066-1283" (2020). Dissertations and Theses. Paper 5567.

https://doi.org/10.15760/etd.7441

This Thesis is brought to you for free and open access. It has been accepted for inclusion in Dissertations and Theses by an authorized administrator of PDXScholar. Please contact us if we can make this document more accessible: pdxscholar@pdx.edu. 
A Land of Poets and Warriors:

The Connection Between Warrior Culture and Bardic Culture in Medieval Wales

c. $1066-1283$

by

Sarah Lynn Alderson

A thesis submitted in partial fulfillment of the requirements for the degree of

\author{
Master of Arts \\ in \\ History
}

\title{
Thesis Committee: \\ John Ott, Chair \\ Brian Turner \\ Chia Yin Hsu \\ Gina L. Greco
}

Portland State University

2020 
(C) 2020 Sarah Lynn Alderson 


\begin{abstract}
Wales in the Middle Ages was a region both divided by war and united by culture. Frequent raids from the Hiberno-Irish, Scandinavians, and Flemish threatened Wales from the outside, while the kings within the borders of Wales fought for supremacy. During the late eleventh century, William the Conqueror made his way to the Welsh border in an attempt to secure his fledging kingdom. Under the premise of protecting his borders, William established the first March of Wales on the eastern border of Wales in 1087. This started the slow process of Anglo-Norman expansion and colonization into Wales.
\end{abstract}

The Welsh maintained a strong warrior culture and frequently raided the Marches, while the violence between the princes continued as well. The Welsh also maintained a strong bardic culture through the Middle Ages, and poets were held in high regard in the princes' courts. These poets were a strong influence on the Welsh princes and encouraged them to fight against the Marcher lords. Poets would often encourage raiding into the March by writing poems to celebrate Anglo-Norman losses and Welsh victories. The poetry and stories written down during the Middle Ages in Wales stressed the value of warrior honor; many heroes die in battle.

This paper relates the ideas of a shared mythic past, military strength, and honor with the Welsh fight to remain independent during the Middle Ages, by showing the considerable influence the literature of Wales had on the behavior of Welsh princes. In fact, Welsh literature was a significant component in the violence of medieval Wales, and not a symptom. The emphasis on violence and strong warriors in the poetry and stories of 
medieval Wales encouraged the princes to raid the Marches in an attempt to keep Wales independent. The bardic culture unified Wales as one people by giving them shared traditions and a shared mythic past, while encouraging strong warrior princes. This paper will utilize the annals Brut y Tywysogion, the literature of the Mabinogi, The Gododdin, and Welsh court poetry. 


\section{Acknowledgments}

I would like to express my great appreciation to Professor John Ott for his assistance and support through this project. His insight into medieval politics and society was truly helpful. He was always willing to listen and to give insight on my thoughts and research. I am grateful for his seemingly inexhaustible patience with my numerous drafts, and his willingness to meet with me about them.

I would like to thank Tim Nidever, who was always ready to help with a tricky translation or share in my excitement over all things Latin. I appreciate his kindness and enthusiasm for both my language skills and this project.

I would also like to thank my husband Jason Alderson for his support through this process. I could not have finished without him. Thank you for reading my drafts and giving me your honest opinion. Lastly I would like to thank Amanda Swinford and David Olsen for acting as sounding boards for my ideas. Speaking with them about our projects helped me formulate and articulate my ideas. 


\section{Table of Contents}

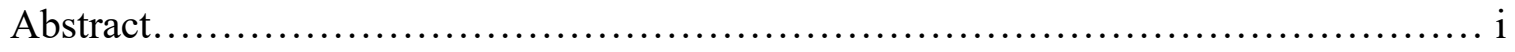

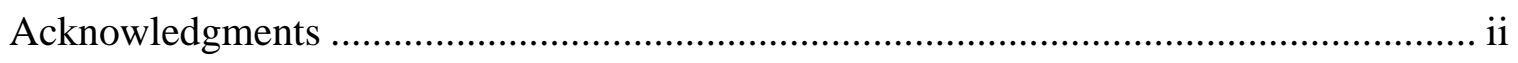

Chapter 1

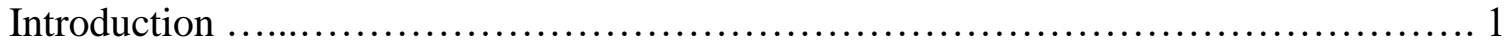

Chapter 2

Poetry for the History Books: Welsh Poetry, Story-Telling and the Historical Record .... 8

Chapter 3

Where 'Chaos' Reigned: The Political Instability of the Region of Wales ............. 37

Chapter 4

From the Outside in: The Norman Colonization of Wales ............................ 55

Chapter 5

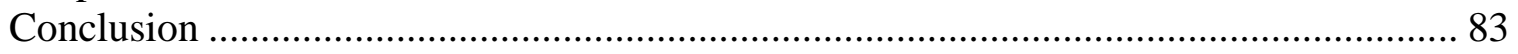

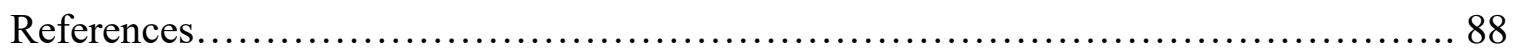

Appendix A

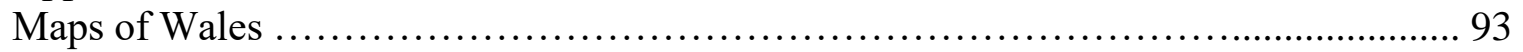

Appendix B

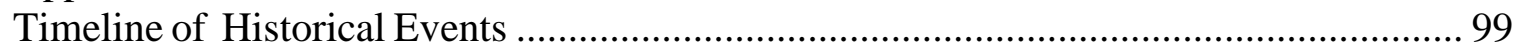

Appendix C

100

Table of texts 


\section{Chapter 1:}

\section{Introduction}

Poetry and stories hold power over people. They are used to entertain, instruct, share, and influence ideas. Cultures have creation myths and epic tales to give their society a history and validity in the world, fables to help teach lessons in morality and common sense, and heroic myths to entertain and teach a sense of pride in one's ancestors, while also building a pantheon of gods and heroes. In many ways poetry and stories sow the seeds of cultures; we are who we are because of our ancestors. Poems and stories have enriched the human experience from time immemorial, and Wales is no exception. Welsh poetry and story-telling in the Middle Ages generated a strong warriorculture and kept the Britons (Welsh) culturally unified despite their lack of political cohesion. The warrior-culture in Wales was met with the colonizing force of the Normans in the late eleventh century when William the Conqueror defeated Harold II at the Battle of Hastings in 1066. Twenty years later, William looked towards Offa's Dyke at the border of Wales with a strategic eye. By 1087 the first March was created, and the Norman expansion into and colonization of Wales had begun.

The twelfth and thirteenth centuries were a time of momentous change in Wales, as it was under siege by Scandinavian (Viking) raiders, Hiberno-Irish, and AngloNormans. ${ }^{1}$ The chronicle Brut y Tywysogion details the Middle Ages in Wales beginning in 694, and brings to light many of the conflicts between the various kings/princes and

\footnotetext{
${ }^{1}$ R.R. Davies, Age of Conquest: Wales, 1063-1415 (Oxford: Oxford University Press, 2000), 2.
} 
outside groups, and the transition from independent region into a part of England after the death of Llywelyn ap Gruffudd in $1283 .^{2}$ The addition of the Anglo-Normans increased the violence in the region and added to its political instability. This is mentioned by David Stephenson in "Medieval Wales: Centuries of Ambiguity," who points out that the addition of the Normans during the late eleventh and early twelfth centuries made the already violent situation worse. ${ }^{3}$

By today's standards, and even to contemporaries who were not Welsh, the fighting, pillaging, and destruction of land both between rivals within and without one's family seems barbaric. Violence appeared to be a way of life for the Welsh. The lack of stable government and the subsequent infighting created a warrior culture centered around the ideals of honor, valor, and ruthlessness in battle; traits used to identify and categorize the Welsh outside of Wales. In turn, the court poets encouraged violence with their poetry and songs of courageous warrior princes from the past and present. They celebrated excursions into the Marches on raids by using as an incentive the literary immortality strived for by princes and warriors, who are fearless and victorious in battle.

The statuses of princes in Wales were heavily influenced by the poems and stories told at courts across the region, as these tales were considered a part of the historical narrative of Wales. Historian R.R. Davies remarks that "in a society based on tradition and custom, the standing of the dynasty was bolstered by the origin-legends, historical

\footnotetext{
${ }^{2}$ Brut y Tywysogion, trans. John Williams Ab Ithel (London: Longman, Green, Longman and Roberts, 1860), 47-271. I am covering the entire two centuries with this statement, therefore using most of the Chronicles to illustrate my point. There will be specifics later in the paper.

${ }^{3}$ David Stephenson, Medieval Wales c. 1050-1332: Centuries of Ambiguity (Cardiff: Wales University Press, 2019), 9.
} 
mythology, and genealogy which had encrusted around it." ${ }^{\text {W }}$ Welsh culture was heavily based in tradition and custom, and well-steeped in historical lore.

These years of political strife and conflict on all sides in Wales have been considered to be the formation of Wales; the Middle Ages have been cited by the scholar Max Lieberman as marking the beginning of the history of England, Wales and Scotland. ${ }^{5}$ This beginning was messy and was both a product and condition of the culture of Wales in the Middle Ages. While Wales did eventually become a part of the English kingdom before its people were able to come together as a true singular force, ${ }^{6}$ Wales was never completely subjugated by England and continued to hold on to the culture and values that made it unique.

Extensive research has been performed on the formation of the March, the Norman conquest, and the poetry and literature of Wales. The consensus of historians lies in recognizing the violence inherent in the region during the Middle Ages, and the Welsh pride of heritage and sense of place. Historian David Stephenson discusses the warring Welsh princes from 1050 until 1332, explaining the nuances of the relationships of the Welsh princes and various outsiders, namely the Anglo-Normans. His work builds on the work of R.R. Davies, who sees Wales as a region with a rich cultural history, which was distinct from its neighbors, but lacking in "political, governmental, or jurisdictional unity." "7 However, both scholars agree that the Welsh exhibited pride for their culture, and

\footnotetext{
${ }^{4}$ Davies, Age of Conquest: Wales, 57.

${ }^{5}$ Max Lieberman, The March of Wales 1067-1300: A Borderland of Medieval Britain (Cardiff: University of Wales Press, 2019), 75.

${ }^{6}$ R.R. Davies, "The Identity of 'Wales' in the Thirteenth Century," in From Medieval to Modern Wales: Historical Essays in Honour of Kenneth O. Morgan and Ralph A Griffiths, ed. R.R. Davies and Geraint H. Jenkins (Cardiff: University of Wales Press, 2004), 63.

${ }^{7}$ Davies, "The Identity of "Wales' in the Thirteenth Century," 48.
} 
their sense of place was evident in their poetry. ${ }^{8}$ For the Welsh, not unlike many cultures, their history was expressed by their literature and poetry. As earlier stated, Max

Lieberman places the beginning of Welsh history in the early Middle Ages, after the Romans evacuated the island. The sixth century seems to be a convenient place to start, as the oldest poems date from the sixth century, when the Welsh were part of the larger group of Britons, and one of their most notable early poems is shared with the Scottish, the Gododdin. ${ }^{9}$ This early poetry influenced poetry in the Middle Ages with the trope of the warrior king, death and victory in battle, and emphasis on the importance for a prince to be a strong military leader.

Despite an acknowledgement that literature has substantial importance in Welsh society, it is rarely recognized in scholarship as having a critical role in Welsh violence. Instead it is used by scholars such as Davies to establish the Welsh as culturally separate from the Anglo-Saxons, Anglo-Normans, and English throughout the Middle Ages. This thesis illustrates the connection between Norman colonization in Wales, Welsh infighting and push-back, and Welsh literature. The war-like nature of Welsh poetry created an obligation for Welsh princes to aggressively establish and maintain territory in order to be immortalized and preserve their honor. The tales accentuated the bravery and nobility of warriors and warrior kings who fought in battles, both mythical and historical.

\footnotetext{
${ }^{8}$ Ibid., 47.

${ }^{9}$ There is some debate over whether it is the oldest Scottish or oldest Welsh poem, as both countries claim it. Scholars seem to consider the poem proof that the Welsh have ties to Scotland in the early Middle Ages. "Book of Aneirin," The National Library of Wales, accessed April 18, 2020. https://www.library.wales/discover/digital-gallery/manuscripts/the-middle-ages/book-of-

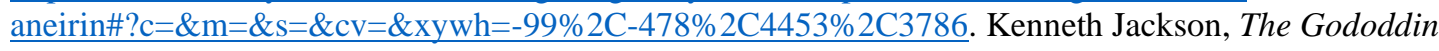
(Edinburgh: Edinburgh University Press, 1969), ix.
} 
All battles featured in poetry were presented as historical fact and gave princes clear expectations of behavior and attitudes, while connecting all of Wales culturally. These facets merged to create the historical narrative of English-Welsh relations: a combination of Norman colonization, civil warfare, and poetry.

The enmeshed relationship between poetry and history meant that the heroic ideals presented in many ancient tales such as the Mabinogi and the Gododdin were repeated consistently in the overarching Welsh historical narrative. These tales and their ideals remained relevant long into the Late Middle Ages. In the story Culhwch and Olwen, for example, the fabled Arthur is a war-chieftain. In the tale, Arthur's abilities are legendary, and so they aid Culhwch in obtaining his marriage to Olwen. ${ }^{10}$ In other poems, great kings are honored for their ability to fight great battles. These poems laid a foundation for a strong warrior-culture centered on military might and all-important honor, which was built upon by contemporary poets during the centuries of Norman conquest. The strong warrior-culture contributes to the fighting between princes and their families. Princes would gather retinues of soldiers in order to be the strongest, and their rivals, whether cousins, brothers, uncles, or even fathers, would maintain their own retinues. The prince/family member with the greatest retinue would hold the title of Prince. The Anglo-Norman kings perceived the Welsh as a threat, owing to their violence, and so took measures to bring them under control. The honor-bound Welsh then fought back against the Normans, who retaliated by building more castles further into

\footnotetext{
10 "Culhwch and Olwen," The Mabinogi and Other Medieval Welsh Tales, trans. Patrick K. Ford, (Berkeley: University of California Press, 2008), 119.
} 
Welsh territory. The introduction of the Norman March also added to the civil strife between Welsh princes by limiting their territories and interfering in Welsh politics. Rather than focusing on inter-Welsh warfare, Norman colonization and Welsh culture separately, this thesis will deviate from the present scholarship by acknowledging the integral role of literature in Welsh politics and Norman colonization during the eleventh, twelfth, and thirteenth centuries.

Cultural identity was important to the Welsh, especially throughout the Middle Ages. This thesis will analyze select primary source materials to show the Welsh voice on shared cultural values and traditions, while also utilizing secondary materials to further conceptualize the contemporary circumstances which also encouraged warrior culture. In Chapter two, "Poetry for the History Books," I will explore poems such as the Gododdin, and stories from the Mabinogi, to illustrate the culture of hero-worship and the expectations of kings/princes. This chapter will also explore the importance of bards in Welsh courts through the tales of Gwion Bach and Taliesin. The third chapter, "Where 'Chaos' Reigned,' considers the violence through the annal Brut y Tywysogion. This paper uses the Brut to show Welsh-on Welsh violence, Anglo-Norman involvement and conquest practices, as well as the change of language that signifies the change in warfare. I will relate this violence to the literary ideals of kingship discussed in chapter two, showing the impact of mythical kings in poetry on contemporary princes. In the final chapter, "From the Outside In," I will consider the effect of Norman conquest in Wales, and how literature influenced the Welsh aristocracy, as well as the Anglo-Norman/Anglo- 
Welsh colonists in the March. I examine three principle writers who were of NormanWelsh mixed descent, and the impact Welsh tales and poetry had on their writing. 


\section{Chapter 2 \\ Poetry for the History Books: Welsh Poetry, Story-telling and the Historical Record}

A good poem is a contribution to reality. The world is never the same once a good poem has been added to it. A good poem helps to change the shape of the universe, helps to extend everyone's knowledge of himself and the world around him.

- Dylan Thomas ${ }^{11}$

\section{'Truth' and 'Reality': The Relationship between Poetry and History}

Poetry in oral cultures holds significant value as a repository of historical knowledge. The poet or bard sings songs of the past which can be connected to historical events - such as real kings or battles — and always hold truth for both the poet and the audience. This relationship between actual historical events and poetic truth has been complicated for modern historians. Historians have often rejected poetry's claim to 'truth' - that which the speaker holds to be true and real, in favor of representations of historical 'reality' - what the facts are and can be proven to be. The question of whether or not poetry can be utilized as an historical source is one that Mauricio Tenorio-Trillo discusses in his book Clio's Law's on History and Language. He explains that "the domains of poetry and history seemed clearly delimited, though always cohabitating as if

\footnotetext{
${ }^{11}$ Charlotte Runcie, "Dylan Thomas: Best Poems and Quotes - which one is your favorite?" The Telegraph Accessed 1/22/20. https://www.telegraph.co.uk/culture/books/11186744/Dylan-Thomas-best-poemsquotes.html
} 
by accident, at least until the first half of the nineteenth century." ${ }^{12}$ Poetry was long considered a form of history by medieval audiences, until scholars changed the definition of history in the nineteenth century. Tenorio-Trillo and modern scholars, however, give poetry a place in the realm of cultural history, where it helps to shape and explain in detail aspects of past societies and their values that are more tenuous and difficult to draw out using nineteenth-century methodologies. While scholars have long used law codes, edicts, and chronicles to perceive historical 'fact,' it is through poetic stories that we learn the contemporary virtues and ideals of a society.

The challenge with using poetry in historical analysis is that poetry transcends history. Tenorio-Trillo states that "poetry comes about within and in spite of history."13 In oral cultures, poets and story-tellers engaged in their arts as a way to impart historical and cultural truths to their audience. While not always historically accurate, in epic poems, truth is reflected in culturally significant examples of expected behavior, an ideal for good leadership, or the consequences of a behavior that society has deemed unfavorable. Poetry and story-telling reflects societal values, the poet's understanding of truth and the values he witnesses and propagates. In short, poetry offers us cultural insights often lacking in political and military history; it defines what it means to be human within the specific period the historian is investigating. In terms of medieval Welsh court poetry, the complex truths found in poetry and prose can be compared to the historical record, owing to the existence of annals. Through the poetry we can see the

\footnotetext{
${ }^{12}$ Mauricio Tenorio-Trillo, "Poetry and History," in Clio's Laws on History and Language, trans. Mary Ellen Fieweger (Austin: University of Texas, 2019), 16.

${ }^{13}$ Tenorio-Trillo, "Poetry and History," 17.
} 
human element of the princes the bard is celebrating, and then use that knowledge to enrich our understanding of the historical narrative of medieval Wales.

\section{Power and Poetry}

As the transmitters of history, the poets held power in Welsh society, and that power is written into their poetry. Patrick Ford examined two Welsh poems which detail the role of poets and poetry in Welsh society. Gwion Bach and Taliesin are two poemsturned-prose pieces that Ford claims are really two parts of the same story. Ford explains that the first part of the tale has an element of magic and speaks to the audience of the "magical drops of poetic inspiration" acquired by Gwion Bach, and his demise at the hands of Ceridwen the witch, who swallows him. Taliesin is more historiographical and gives insight into the customs and manners of the court, indicating it may have been intended for an entirely different audience and setting. ${ }^{14}$

According to the story, Gwion Bach was a servant from "the days when Arthur began to rule," ${ }^{15}$ and he worked in the household of Tegid Foel and the witch Ceridwen. Together, Tegid and Ceridwen had a son who was hideous to look at. To make up for his appearance, Ceridwen made three drops of a potion that would make the ingester "extraordinarily learned in various arts and full of the spirit of prophesy." Gwion Bach is then set by Ceridwen to maintain the fire under the cauldron for "one year and a day." As the story goes, Ceridwen took a nap to wait, and when the time came for the potion to

\footnotetext{
${ }^{14}$ Patrick K. Ford, "The Tale of Gwion Bach and the Tale of Taliesin," in The Mabinogi and other Medieval Welsh Tales, ed. Patrick K. Ford, (Berkeley: University of California Press, 2009), 159.

${ }^{15}$ Traditionally this is set with the departure of the Romans. Both Arthur and Maelgwn Gwynedd are mythical-historical kings put into the sixth century by Ford in this case. Ibid., 160.
} 
"spring forth from the pot," Gwion Bach pushed Morfan, Ceridwen's son, out of the way and took the drops himself. In her anger, Ceridwen chased down Gwion Bach and swallowed him. After nine months, she gave birth to him, put him in a basket and threw him into the water. ${ }^{16}$ This story is meant to explain how the great poet and prophet Taliesin came to be, but it can also symbolically show how poetry in the courts first started. The first poet, Gwion Bach, took the knowledge of the world for himself and then was reborn into Taliesin, the poet of legend.

Taliesin gives a glimpse into courtly behavior, with the son of a king's squire as the hero. Elphin is the son of Gwyddno, a squire to king Maelgwn Gwynedd. Gwyddno had squandered much of his wealth, and left Elphin penniless and unable to "maintain a social life and keep company with [his friends] in the manner he had been accustomed to." Elphin then decided to ask his friends to gather fish from the weir (a dam) for him "next All Hallow's eve." They are granted permission and go. While they are there, they see no fish, and just as Elphin is in despair, he sees that a basket is in the weir, and within the basket is a human, whom Elphin names Taliesin, meaning "behold the radiant forehead. ${ }^{17}$ For the rescue of Taliesin Elphin is rewarded with great wealth, putting him in a position to rival King Maelgwn. ${ }^{18}$ Elphin likewise gains Taliesin as a poet to rival those of Maelgwn, earning himself a prestigious position: "at that time poets were received with great esteem among the eminent ones of the realm," who were required to be "learned men $[\ldots]$ steeped and skilled in pedigrees, arms, the deeds of kings and

\footnotetext{
${ }^{16}$ Ibid., 163-164.

${ }^{17}$ Here, the text says, "As soon as Elphin saw the forehead, he said, 'behold the radiant forehead' (i.e., Taliesin)!" "Gwion Bach and Taliesin," 165.

${ }^{18}$ Ibid., 165-167.
} 
princes of foreign kingdoms as well as the ancestors of this kingdom, especially in the history of the chief nobility." ${ }^{19}$ Elphin, knowing this, choses to boast to his men of his newfound wealth, his wife, and his poet who brought him his fortune. The boast is in poor taste, and owing to it, King Maelgwn captures both Elphin and his wife and holds them in his palace.

Taliesin journeys to the court of King Maelgwn to rescue Elphin and his wife. Upon his arrival, he proceeds to rescue Elphin with magical poetry. In his verse to the poem's antagonist King Maelgwn, Taliesin mentions several branches of the Mabinogi, calls himself Merlin, references the Britons as the descendants of Troy, and mentions himself in several biblical stories:

The king asked him what he was called, and he answered him saying this:

Johannes the prophet called me Merlin,

But now all kings call me Taliesin.

Then the king asked him where he had been, and thereupon he recited his history to the king, as follows here in this work:

I was with my lord in the heavens

When Lucifer fell into the depths of hell;

$[\ldots]$

I witnessed the destruction of Sodom and Gomorrah;

I was in Africa before the building of Rome;

I came here to the survivors of Troy.

${ }^{19}$ Ibid., 167. 


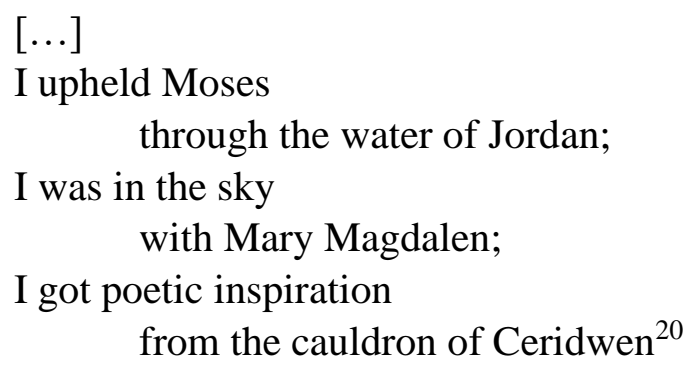

The import of Taliesin lies in the power Taliesin holds as a poet. When Elphin finds him in a basket on a weir and takes Taliesin home, he is blessed with wealth: "From that moment on, Elphin's wealth increased more and more each succeeding day." 21 Taliesin proves his gratitude for his rescue by Elphin in faithfulness. Taliesin's magical use of poetry convinces Maelgwn to let Elphin go, and he recites a poem of his intention ending with:

\section{Elphin son of Gwyddno \\ Suffers torment now, 'Neath thirteen locks \\ For praising his master-bard. \\ And I am Taliesin, Chief-poet of the West, And I shall release Elphin From the gilded fetters. ${ }^{22}$}

After Taliesin ends the poem, "he sang a song of succor, and they say that instantly a tempestuous wind arose, until the king and his people felt that the castle would fall upon them.."23 Out of fear for his life, his court, and his hall, Maelgwn is forced to free Elphin.

\footnotetext{
20 "Gwion Bach and Taliesin," 172-173.

${ }^{21}$ Ibid., 167.

${ }^{22}$ Ibid., 174.

${ }^{23}$ Ibid., 174.
} 
Taliesin then recites "Interrogation of the Bards," "The rebuke of the Bards," and "The Satire on the Bards," which "silenced the bards so that none of them dared say a single word." ${ }^{24}$ As earlier in the poem, after his rescue, Taliesin brought Elphin great wealth by instructing Elphin to dig up a cauldron full of gold as payment for rescuing Taliesin from the weir.

The loyalty of Taliesin as court poet for his rescue and care by Elphin demonstrates the benefits for a person who shows kindness to his poets. The chastisement of Maelgwn in return for the imprisonment of Elphin, to whom Taliesin feels loyalty, depicts poets as having magical abilities. In this foundational poem, the implication of the power a poet holds over a prince is spelled out within the text. Taliesin and Gwion Bach give poets a place of importance and honor as the bearers of truth and hold them to the ideal of honor and loyalty to their prince/patron.

\section{Poetry and the Welsh Cultural Narrative}

Despite the political instability of Wales during the Middle Ages, the Welsh had long been considered and considered themselves a single people, separate from the peoples on the rest of the island of Britain. In "The Identity of 'Wales' in the Thirteenth Century," historian R.R. Davies claims that "literary and legal sources in particular indicate alongside the memory of the Island of Britain as a single entity there existed a sense of Wales and its boundaries. Clawdd Offa, Offa's Dyke, demarcated the land boundary of Wales in the native law texts, as it had once done for Asser in Alfred's

${ }^{24}$ Ibid., 175-177. 
day." 25 The idea of a common culture shared among the people of Wales created a strange sort of unity that made the Welsh different from their Anglo-Norman and English neighbors, and helped the princes drum up support for the raids into the march and later rebellions. Moreover, the instability of the region, especially in the face of Norman and English incursion, and the instability of the relationships between the Welsh princes, created circumstances in which rulers sought to maintain their power by all means available.

In The Age of Conquest: Wales 1063-1415, Davies lays out the foundations of princely power in Wales. Among warrior culture, court practices and movement, and lineage, Davies emphasized the role of mythology and kingly appearance and most importantly, remarks on the relevance of poetry in Welsh society. Davies tells us that Welsh politics were "conducted within what may be called an ideological and mythical framework to which all Welshmen subscribed," and the "framework of beliefs, rhetoric, and aspirations had been shaped over generations. Its primary keepers and transmitters were the court poets, $[\ldots]$ who underwent a long apprenticeship in the traditional linguistic, literary, and historical lore of Wales." ${ }^{26}$ Welsh culture was connected by its history, which was transmitted through its poetry, and the poets were the historians. This dynamic created a status of power and importance in medieval Welsh courts for the bards; they were patronized by the rulers and the princes' retinues. The poems and stories

\footnotetext{
${ }^{25}$ Davies, "The Identity of 'Wales' in the Thirteenth Century,", 47.

26 The full quote is, "This framework of beliefs, rhetoric, and aspirations had been shaped over many generations. Its primary keepers and transmitters were the court poets, a small coterie of men who underwent a long apprenticeship in the traditional linguistic, literary, and historical lore of Wales." R.R. Davies, "Native Wales 1063-1172: Power, Conflict, and Hegemony," in Age of Conquest, 77.
} 
were offered as the evening's entertainment in the halls, and as such were meant to delight as well as serve as propaganda for the princes.

The Welsh poets used poetry to explain and connect with their history, giving the Welsh an identity by rooting it in historical validity in the mythic past. Davies writes that "two aspects of that past were especially emphasized. One was the unbroken link between the Old North (W. Yr Hen Ogledd) - the kingdoms of North Britain of the fifthseventh centuries - and the contemporary political order in Wales." 27 The poem The Battle of Argoed Llwyfain, attributed by Tony Conran to the sixth-century poet Taliesin, provides an example. This poem refers to a battle with Rheged and Goddau (Gododdin) in far northern England and southern Scotland:

The fourfold hosts of Fflamddwyn invaded.

Goddau and Rheged gathered in arms, Summoned from Argoed as far as Arfynydd They might not delay by so much as a day. ${ }^{28}$

This poem grounded Welsh identity in their deep history. Contemporary Welsh people could say they had belonged to the island for millennia - their ancestors had fought bravely against the Picts with legendary kings of the Old North. This gave the Welsh what Davies refers to as "an intense pride in the past." 29 This past connected all of the Welsh through the pride of their history - they had always been fierce warriors, called upon to fight to preserve the land that belonged to them as a people.

${ }^{27}$ Davies, "The Identity of 'Wales' in the Thirteenth Century," 78.

${ }^{28}$ The Battle of Argoed Llwyfain, Welsh Verse, ed. Tony Conran (Bridgend: Wales Poetry Press, 1986), 111.

${ }^{29}$ Davies, "The Identity of 'Wales' in the Thirteenth Century," 78. 
According to historian Kenneth Jackson, The Gododdin is a series of eulogies about Brittonic warriors ${ }^{30}$ thought to have been composed in the late sixth or early seventh century by the poet Aneirin. Aneirin is easily identified as the author of the eulogies, as he names himself in the beginning of the Gododdin. Aneirin was reportedly contemporary to the late sixth century, and Jackson states that the poems are clearly written in reference to warriors known personally by Aneirin owing to the language and tone in which they are written. He also claims that the events described in the Gododdin can only be ascribed to the turn of the seventh century. ${ }^{31} \mathrm{C}$. Cessford also dated the Gododdin to the turn of the seventh century using geography and known historical events. In "Northern England and the Gododdin Poem," Cessford reasons that newer translations of the poems bring to light a reference to a warrior, Madog Elfed, whose name means Madog from Elmet, in northern England. Cessford remarks that by 616, the region of Elmet was under Anglo-Saxon control, dating the poem prior to $616 .{ }^{32}$

The eulogies list many warrior's names, and several are mentioned in other texts, such as Bradwen and Moren Mynawg, who are listed in the legendary Arthur's retinue in Culhwch and Olwen, along with Urien of Rheghed, a relation of Arthur's. Jackson also points out that the warrior Pobddelw found in the Gododdin is also listed in Welsh genealogy as a king of Dunoding in Gwynedd. ${ }^{33}$ The fact that there are warriors in the

\footnotetext{
${ }^{30}$ Brittonic refers to the people indigenous to the island before the Anglo-Saxon invasions and the ancestors of the Welsh.

${ }^{31}$ Jackson discusses the differences in the poetic voice between a poem composed contemporary to the event and a poem composed later. He uses other poetic narratives in the Celtic tradition as comparative examples. Kenneth Jackson, The Gododdin, (Edinburgh: Edinburgh University Press, 1969), 3 and 56-58.

32 C. Cessford, "Northern England and the Gododdin Poem," Northern History 33, no.1 (1997): 220.

${ }^{33}$ The significance of the warriors featured simultaneously in the Gododdin, Culhwch and Olwen, and Welsh Genealogy is that they show the intertwined nature of history and literature for the Welsh in the
} 
Gododdin who are also mentioned in other medieval Welsh literary texts shows how Welsh literature and history were woven together to create a narrative easily passed down in the form of poetry and prose. The heroes are featured across multiple tales and constitute a pantheon of Welsh heroes whose legends helped to encourage a sense of cultural connectivity and importance for the Welsh people sharing in this heritage.

While the original text does not survive, a thirteenth-century copy is currently held in the National Library of Wales in Cardiff. According to the library, this particular copy is the oldest surviving, and is composed in Welsh. ${ }^{34}$ This group of poems is centered around the tribe of Britons living in southern Scotland, called the Gododdin, from whom the Welsh drew much of their inheritance and history. According to Conran, "the poem that is called The Gododdin is a series of heroic elegies, [...] commemorating the bravery and deaths of the British warriors who 'paid for their mead' with their lives. ${ }^{{ }^{35}}$ Featured prominently is the idea of bravery unto death in battle; in one poem Aneirin, to whom Conran attributes the poems, refers to the bravery of the warrior:

Quicker his blood to earth Than to his wedding. ${ }^{36}$

Mixed with the stories of battles, there are also stories of feasting:

\footnotetext{
medieval period. The Mabinogi and Other Medieval Welsh Tales, trans. Ford, 126-127. Jackson, The Gododdin, 22.

34 "Book of Aneirin," The National Library of Wales, accessed April 18, 2020. https://www.library.wales/discover/digital-gallery/manuscripts/the-middle-ages/book-ofaneirin\#? $\mathrm{c}=\& \mathrm{~m}=\& \mathrm{~s}=\& \mathrm{cv}=\& \mathrm{xy} w \mathrm{w}=-99 \% 2 \mathrm{C}-478 \% 2 \mathrm{C} 4453 \% 2 \mathrm{C} 3786$

35 The full quote is "The poem that is called The Gododdin is a series of heroic elegies, in no perceptible order as we have it, commemorating the bravery and deaths of the British warriors who "paid for their mead' with their lives." Tony Conran, "From The Gododdin," in Welsh Verse, ed. Conran, 113.

${ }^{36}$ Ibid., 113.
} 
Gwlyged of Gododdin served them most readily:

He made famous and costly Mynyddawg's feast

In order to buy back the country of Catraeth. ${ }^{37}$

The English also feature in the poems, and they were likely inserted anachronistically when they were written in the later Middle Ages. The tone of the poem is mournful and laments the loss of all the warriors but one (presumed to be Aneirin), while also glorifying the warriors who fought and gave their lives for the Welsh (or at the time, Britons). The twelfth stanza shows the glory given to the warriors:

Three hundred golden-torqued men attacked:

Contending for the land was cruel.

Although they were being slain, they slew;

Till the world ends, they will be honoured.

Of the comrades who went together,

Tragic, but a single man returned. ${ }^{38}$

The sixth-century poet Taliesin also writes of these early warriors and their fight to repel the Anglo-Saxon invaders. In "Death Song for Owain ab Urien," Taliesin writes that Owain ab Urien is "without peer" and calls him the "reaper of enemies." 39 While both of these poets were originally writing and singing their poems in the sixth century, this oral tradition was only copied down by monks in Wales, when the Welsh aristocracy was fighting against Norman subjugation.

\footnotetext{
${ }^{37}$ This poem also references the Romans and how the Britons miss them: "So long to grieve for them, and yearn/ For those fiery men, from a land of wine!" Ibid., 115

${ }^{38}$ Conran, "from The Gododdin," 6.

39 "Death Song for Owain ab Urien," The Oxford Book of Welsh Verse, 2.
} 
Thirteenth-century poems also followed the tradition of the heroic warrior, for example "In Praise of Owian Gwynedd":

I praise a patron high-hearted in strife,

Wolf of warfare, challenging, charging,

Singing the pleasure of his presence,

Singing his power, mead-nourished worth,

Singing his fervor, swift-winged falcon,

[...]

Ardent the lord, sword bright above sheath,

Spear in strife and outpouring from sword,

Sword-blade in hand and hand hewing heads,

Hand on sword and sword on Norman troops,

$[\ldots]$

In hosts we went, for his prize, for his praise,

Many minstrels for Owain's bounty,

$[\ldots]$

They were not, Gwynedd's valour, mere boys:

You were fearless, shepherd of Britain. ${ }^{40}$

The idea of the Welsh warrior being praised for his swiftness in battle and his ability to

kill his foes, was an important motif in Welsh poetry. Another poem, "Lament for

Llywelyn ap Gruffudd," likewise highlights the prince's valor and fearsomeness:

A lord like a lion leading his land,

A lord chafing for devastation.

A lord who prospered, til he left Emrais

No Saxon would venture to strike him,

A lord, stone is his roof, Welshman's monarch,

Of the right line to rule Aberffraw. ${ }^{41}$

40 "In Praise of Owain Gwynedd," The Oxford Book of Welsh Verse, 25.

41 "Lament for Llywelyn ap Gruffudd," The Oxford Book of Welsh Verse, 31-32. 
Llywelyn ap Gruffudd and Owain ab Urien were both important to the poet because they were strong warriors in battle, making them the ideal Welsh princes. By singing of the warrior princes and making them special because of these traits, the poets created an expectation and model for other princes to aspire to.

A prince worthy of song was one who could and would defend his land and his people to the death and would have descended from a strong princely dynasty. A strong princely dynasty depended on genealogy, origin-legends and historical mythology for strength and validity, ensuring that it was imperative for a prince to have the support of a poet. ${ }^{42}$ While Davies later goes on to explain that "military prowess and person mastery ${ }^{\prime 33}$ are also significant, the history and mythical origins of a dynasty, brought to the forefront by poets, was the base from which the military prowess would have to be built. Therefore, the power held by the poets was increased by the need for princes to prove their own prowess, while also having proof of their noble family history.

As the border of the Anglo-Norman kingdom developed from the eleventh through the thirteenth centuries, the poets turned to encouraging attacks on the March by the princes. According to Stephenson, "for the poets, carrying war into the Marches although they hardly use the word or make precise reference to the concept - was still one of the characteristics of a true leader." ${ }^{44}$ Owing to the long tradition of the glorification of strong warrior-kings fighting to protect Welsh land, the poets did not need to do more than tell the stories the princes had grown up hearing. The pressure to live up

\footnotetext{
${ }^{42}$ Davies, Age of Conquest: Wales, 1060-1415, 57.

${ }^{43}$ Ibid., 59.

${ }^{44}$ Stephenson, Medieval Wales c. 1050-1332: Centuries of Ambiguity, 71.
} 
to the expectation of a noble Welsh prince would have made the idea of princely duty immortalized in poetry the final push for the princes to raid the March. According to Davies, "the leaders of native Welsh society in our period were hard-drinking, lustful warriors, exulting in prowess, sensitive to a fault of their honour, conditioned by a social code which preached the necessity of vengeance and the shame of dishonour." 45 While it is likely that the princes would have fought against the March without the instigation of the poets, it is also likely that the poetry the princes grew up hearing helped to perpetuate the social code into one that created princes who were overly sensitive to their honor. Poets used their power as the writers of history to show the bloody legacy of Wales and bolster the Welsh claim to independence and their historical ties to the north of Britain, while continuing the tradition of warrior-princes. These poems created Welsh unity separate from the Anglo-Normans, and a culture of princes eager to defend that unity.

\section{The Mabinogi}

While the oral tradition of Welsh poetry reaches far back, some of the older poems were retold as prose, with parts remaining as poetry, for example, the poem Gwydion sings to Lleu in Fourth Branch of the Mabinogi. Tony Conran remarks that the three, four-line stanzas of poetry are "older than the prose, and could well be the remnant of much more extensive verse passages." ${ }^{46}$ The Mabinogi is one of the best sources for Welsh prose in the Middle Ages, because of its length, magical elements, and mysterious authorship. The stories have engaged scholastic interest in a variety of aspects of the text,

\footnotetext{
${ }^{45}$ Davies, Age of Conquest: Wales, 1063-1415, 76.

${ }^{46}$ Conran, "The Mabinogion," in Welsh Verse, 135.
} 
from the identity of this unknown author, to the intention of the writer, to what the text is telling its readers, both contemporary and modern. Various assumptions have been made that the Mabinogi was written by a woman, that it was the Welsh equivalent of a "mirror for Princes," or that it explores sexual transgressions.

In "Warlords and Diplomats in the Four Branches of the Mabinogi," for example, historian Andrew Breeze argues that the Mabinogi was written by a woman. He identifies her as Princess Gwenllian, who was married to Gruffydd ap Rhys of Dyfed and the daughter of Guffudd ap Cynan of Gwynedd. ${ }^{47}$ Breeze acknowledges the incredible nature of his claim - not many Welsh women, aristocratic or not, would have been able to write such a text in the twelfth century. To Breeze, the heavy emphasis on diplomacy rather than warfare provides evidence as to the nature of the author. The major evidence Breeze offers is that in the case of warfare in the Mabinogi, "the author of these stories knew a great deal and almost nothing."48 The lack of named weapons, battlefield deaths, and strong descriptions of weapons in the text are suspicious to Breeze. The pages are full of violence, but according to Breeze, the type of violence in the story is not the same as the violence of war, and concludes from this that "the author had no direct experience of combat, and was not interested in this age-old male pursuit.. ${ }^{\prime 49}$ For Breeze, the lack of distinct and descriptive weapons and warfare, paired with frequent councils and kings who take advice, marks the author as the princess Gwenllian. The question that remains

\footnotetext{
47 Andrew Breeze, "Warlords and Diplomats in the Four Branches of the Mabinogi," in War and Peace: Critical Issues in European Societies and Literature 800-1800, ed. Albrecht Classen and Nadia Margolis (Berlin: De Gruyter, 2011), 169.

${ }^{48}$ Breeze, "Warlords and Diplomats," 160.

${ }^{49}$ Ibid.
} 
to be answered is whether it is probable that a woman would have authored anything at this time. The lack of named weapons and war scenes could have other meanings, such as a call to reject battles and settle into a more "civilized" way of life. ${ }^{50}$

While the thought of a female author is tantalizing, Helen Fulton writes that the Mabinogi performs "among other things, an educative function for the nobility of Wales, contributing a native version of the speculum principium." ${ }^{51}$ She explains that the ideology of a "mirror for princes" was increasingly popular during the Middle Ages all over Europe, and that the stories of the Mabinogi are not often mentioned by court poets, who focus on other figures in mythology. ${ }^{52}$ This is important in her argument, as it places the Mabinogi as a text that would not be intended for the general public. Fulton agrees with Breeze that the text was written with an aristocratic audience in mind, and this is a seemingly inarguable point — the stories of the Mabinogi concern princes and princely behaviors. The timing fits for the most part into Fulton's thesis — during the late twelfth and thirteenth centuries, Wales was in political turmoil, and was increasingly subjugated by the Anglo-Normans as the Marches were expanded. However, in the late twelfth and early thirteenth century Llywelyn ap Gruffydd had attempted to unify and hold Wales as a single principality. ${ }^{53}$ According to the medieval Welsh Chronicle, the Brut $y$ Tywysogion, Llywelyn was the last "prince” of Wales, before Roger Mortimer besieged Dolvorwyn Castle in central Wales east of Aberystwyth, and all of the south of Wales

\footnotetext{
${ }^{50}$ The idea of living more "civilized" and with less violence also follows ideals that can be ascribed to monks. ${ }^{51}$ Helen Fulton, "The Mabinogi and the Education of Princes in Medieval Wales," in Medieval Celtic Literature and Society, ed. Helen Fulton (Dublin: Four Courts Press, 2005), 230.

${ }^{52}$ Fulton, "The Mabinogi and the Education of Princes in Medieval Wales," 232.

${ }^{53}$ Stephenson, Medieval Wales c. 105-1332, 20-26.
} 
became part of England. Shortly thereafter, Llywelyn married Eleanor, the daughter of Simon Montfort, an English noble, and within a decade, Wales was no longer sovereign. ${ }^{54}$ Despite the fact that Llywelyn was able to control most of Wales from Gwynedd, his ascension was wracked with battles and strife, dissension from his cousins and fellow princes, and even difficulties with King Edward II. The English were attacking the Welsh, and the Welsh continued raiding the March. The biggest difference in behavior was that Gwenydd seemed to dominate the rest of the principalities, and Wales was in its final throes. During this turmoil, however, a manuscript dictating to the princes a correct way to act, replete with diplomacy over battle (although some battles are implied, and all are fought from a distance to the reader), and where honor and glory are emphasized in noble behaviors rather than reckless bravery, could be a move by a sympathetic clergyman, lord, or even a prince to encourage behavior that could unite the Welsh princes against the Anglo-Norman/English aristocracy so that Wales could remain independent.

Fulton goes into detail about the use of the term 'prince,' versus 'king,' which is also a distinction that David Stephenson points out in Medieval Wales, Centuries of Ambiguity. For Fulton, before the thirteenth century, the kings of the different regions of Wales were equal in their own right. However, the rise of Gwynedd and the growth of Norman feudalism into the thirteenth century saw the Welsh princes become subjects of the prince of Gwynedd, who was in turn subject to the English king. ${ }^{55}$ For Fulton, this

\footnotetext{
${ }^{54}$ Brut y Tywysogion, trans. Williams Ab Ithel, 363.

${ }^{55}$ Fulton, "The Mabinogi and the Education of Princes in Medieval Wales," 234.
} 
marks the end of traditional kingship in Wales, effectively ending its status as a separate place geographically from the rest of England. Stephenson, however, seems to believe that the term 'prince' held more power than 'king' to the Welsh, and that uniting under one ruler was paramount to success against the English. Therefore, the princes of the regions in Wales would unite under one king of greater Wales in order to fight against English rule. ${ }^{56}$ Fulton remarks in her conclusion about the changing nature of kingship throughout the Four Branches: "regional prince, national king, regent on behalf of an inexperienced prince, and boy-prince in waiting - [all] display a range of lordship roles available to Welsh princes of the thirteenth century, all of them positioned within a normative feudal framework." ${ }^{57}$ According to Fulton, "the tales are dynamic examples of good leadership in action." 58 She explains that they present a guidebook on how to run a kingdom well, with answers about succession, preservation of peace, and continued power. The kings in the Mabinogi rule over their respective principalities as feudal lords, but, as Stephenson and Fulton point out, in service to the king of England.

Michael Cichon also likens Welsh poetry and prose to social morality tales, but in many ways he emphasizes their condemnation of illicit sexual behaviors. His essay, "Gross Sexual Transgression in the Mabinogi," can be summed up in two sentences in its conclusion: "Describing romances and erotic situations is not the main purpose of the redactor: his narrative is more related to social situations, although these are all driven by

\footnotetext{
${ }^{56}$ Stephenson, Medieval Wales c. 1050-1332, 38.

${ }^{57}$ Fulton, "The Mabinogi and the Education of Princes in Medieval Wales," 246.

58 Ibid.
} 
lust. In effect, he uses the erotic potential of his tale to moralize." ${ }^{59}$ Rather than a Welsh version of the Mirror for Princes, the Fourth Branch is meant as a moralizing tale of sex and sexual violence. Cichon looks closely at the expectations of female purity, the taboo, and the consequences of adultery as the main vein of the Fourth Branch. The tale is disjointed in places, and the story seems to focus simply on Math, who is a magician, and his family. Goewin is raped by Gilfaethwy and Gwydion, whom Math turned into a male and female animal. Their animal forms changed every year for three years, and every year they were required to mate and bring him their child. Math also married Goewin so that he could lawfully avenge her shame. ${ }^{60}$ Cichon argues that this is a symbolic punishment, and that "the bestial nature of the criminals is emphasized by their transformation into wild animals." 61

Cichon later discusses the story of Aranrhod, who claimed to be a maid, but was not. In the story, Math is required to have a maid to rest his feet on for his survival: "in those days, Math son of Mathonwy could only live while his feet were in the lap of a

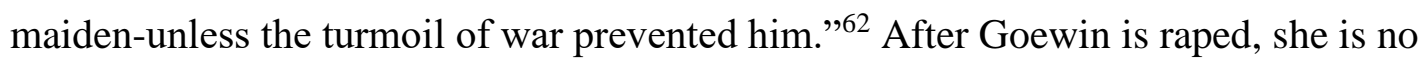
longer a maid and so Math must find a new maid to rest his feet on. Gwydion brings Aranrhod to him, and when asked about her virginity she claims that she is intact.

\footnotetext{
${ }^{59}$ Michael Cichon, "Eros and Error: Gross Sexual Transgression in the Fourth Branch of the Mabinogi," in The Erotic in the Literature of Medieval Britain, eds. Amanda Hopkins and Cory James Rushton (Cambridge: D.S. Brewer, 2007), 115.

${ }^{60}$ Cichon notes that the rape of a woman is considered a crime against her husband and male kin, and that it is also the duty of a king to protect his female subjects. The fact that Math married Goewin shows his acceptance of responsibility for his failure to protect her. Ibid., 108.

61 Ibid.

${ }^{62}$ This is an example of a geis found in Celtic stories - while the story does not specify, Math was likely given this geis by another sorcerer or an entity from the otherworld, as a punishment on himself or his parents. "Math son of Mathonwy," in The Mabinogi and Other Medieval Welsh Tales, 91.
} 
Aranrhod, however, is not a virgin. She is found out when Math has her leap over his magic rod and when she jumped over it "she dropped a big, fine, yellow-haired boy."63 Aranrhod ran away, and when she is sought out to give the boy a name, curses him to remain nameless unless she gives it to him, to have no weapons unless she outfits them for him, and no wife that is "from any race that is on this earth now." ${ }^{64}$ Cichon argues that Aranrhod faces no real consequences for her immoral behavior, and instead, ultimately it is her son who will pay the price. Aranrhod is tricked into giving him the name Lleu and arming him, but the third curse is one that she cannot be tricked into breaking. Math eventually makes a wife for Lleu out of flowers, and she is named Blodeuwedd. Blodeuwedd falls in love with a mystery man named Gronw and makes plans with him to kill Lleu. While Lleu manages to escape Blodeuwedd in the form of an eagle, his uncle Gwydion later finds him putrefying and must restore him. Blodeuwedd is then punished by being changed into an owl by Gwydion. ${ }^{65}$ Cichon believes that the transformations of Lleu, Blodeuwedd, Gwydion, and Gilfaethwy are all connected by illicit sex: whether the act of rape, being cuckolded, or being unfaithful to a spouse. ${ }^{66}$

These three differing views of the purpose and authorship of the Mabinogi help to show the importance of the text to the history of medieval Wales and the range of scholarly opinion. While the stories are not historical in nature, they tell a story about the contemporary society in which they were written. The text was written the twelfth

\footnotetext{
${ }^{63}$ The Mabinogi and Other Medieval Welsh Tales, 98.

${ }^{64}$ Ibid., 102.

${ }^{65}$ Ibid., 107-108.

${ }^{66}$ Cichon, "Eros and Error," 113.
} 
century, but the stories, as in many cultures of oral tradition, possibly go much farther back. In the case of the Mabinogi, audiences are given a snapshot of twelfth-century ideas of morality and honor rather than a series of events. Ultimately, the significance of the stories lies in who they were intended for. Were they stories meant to thrill and instruct all audiences, or were they meant to instruct princes on diplomacy? When looking at the scholarship of Cichon, Fulton, and Breeze and reading the texts, it is easy to see how these stories have elements which would have been relevant to both men and women, the elites, and the common classes. This is part of the charm of the Mabinogi - it is a chameleon text that can morph to the purposes which would best serve whatever audience was listening or reading.

\section{Reimagining Welsh Storytelling for an English Court}

Celtic storytelling is unique. Welsh storytelling fits under this umbrella with Irish tales such as the Táin, and the Breton Lais of Marie de France. Typically, there are encounters with the otherworld, and geis-a magical taboo put on the hero which carries the punishment of misfortune or death for defiance-are often placed on heroes, and many of the stories are filled with magic and an element of danger. Even today, many of these stories and story-telling styles continue to enchant readers. This uniqueness caught the eyes of Geoffrey of Monmouth and Walter Map, two ecclesiastics from the March of Wales. Growing up in the March, Geoffrey of Monmouth and Walter Map would have been exposed to these stories, as well as the violence of the Welsh. Walter Map's De Nugis Curialium and Geoffrey's Historia Regum Britanniae reflect both experiences in the way they use Welsh fantasy to instruct and give opinion. While their writings 
obviously express disdain towards the violent warfare of the Welsh, their focus is on recreating and celebrating the style and imagination of Welsh poetry and story-telling.

Geoffrey of Monmouth was writing during the anarchy of England - Mathilda, the daughter of Henry I (1100-1135), was fighting for the throne that her uncle Stephen of Blois had taken at the death of her father, and the country was in an uproar. The Welsh, seeing an opportunity, used this time of unrest to increase raiding in the March and to take back considerable Welsh territory. ${ }^{67}$ Welsh raiding increased during Stephen's reign (1135-1154), and Geoffrey, whose family were lords of the March, would have had ties to areas under attack. Geoffrey grew up in the March, most likely knowing what it was to fear a Welsh raid, but also to enjoy instructive tales or the poetry of the Welsh. The Mabinogi was likely written down while Geoffrey was an adult, but the stories or similar stories by the Welsh were available, such as the tales of Taliesin, Culhwch and Olwen, and Lludd and LLeuelys. It would not have been uncommon for Marcher lords and their families to know and understand traditional Welsh stories and poems. According to Stephenson, "In many ways the March was much less a barrier to contact between English and Welsh, but rather a conduit." ${ }^{68}$ Living in the conduit of Welsh and English culture, it was not unlikely that after growing up hearing the stories, Geoffrey developed a love for Welsh folk tales.

When reading the Historia, it is possible to see the Welsh storytelling in his writing. Geoffrey particularly focuses on the then-obscure King Arthur and the concept

\footnotetext{
${ }^{67}$ Lieberman, The March of Wales 1067-1300, 24.

${ }^{68}$ Stephenson, Medieval Wales c. 1050-1332, 76.
} 
of the Welsh hero who will one day come back and rule all of Britain. Geoffrey was the first to write out the legend of Arthur and the Prophecy and Life of Merlin, and his tradition mushrooms throughout the Middle Ages and onto the continent. It is, however, pulled from a less voluminous but no less epic tale about a war-chief named Arthur from the tale of Culhwch and Olwen. In the tale, Arthur was a leader of a group of Huntsmen, and the cousin of Culhwch, who calls upon Arthur to perform several Herculean tasks in order for Culhwch to be able to marry Olwen. ${ }^{69}$ While in this story Arthur is a great warrior, a leader of men with a court and retinue, and he manages to finish all the tasks so Culhwch can win Olwen, he is not the famous hero from Geoffrey's tale. The tradition of great warrior kings is not limited to Culhwch and Olwen, either. Poems such as The Battle of Argoed Llwyfain, the Death Song of Owain ab Urien, as well as The Gododdin mentioned earlier, give praise to ancient warriors who had won and lost battles in the mystic past of the Britons in the southern part of Scotland, dying in a battle he won. ${ }^{70}$ There can be little doubt that Geoffrey was taking inspiration from these tales, and possibly from many others, in order to write the Historia.

Geoffrey draws heavily from Taliesin for his Prophetiae (Merlini), and for his character of Merlin more generally. Taliesin calls himself Merlin in his poem to Maelgwn when he first introduces himself to the king. He then proceeds to explain his history, which, at one point, involves telling the king "I came here,/to the survivors of Troy.",71 Both of these pieces of information find themselves in the Historia: Geoffrey starts the

\footnotetext{
${ }^{69}$ The Mabinogi and Other Medieval Welsh Tales, 126.

${ }^{70}$ Conran, "The Battle of Argoed Llwyfain, Death Song for Owain ab Urien," 111-112.

${ }^{71}$ Ibid., 173.
} 
Historia with an explanation of how Brutus came from Troy to settle Britain. ${ }^{72}$ After a long series of fighting, in which Brutus and his men battle their way to the Gauls in northern France, they sail to the Island:

The Trojans pursued, hacking and killing, and did not cease until they had secured victory. Brutus was most satisfied with this triumph, but anxious because his numbers were diminishing every day, whilst those of the Gauls grew continually. At last, doubting the wisdom of a protracted struggle, he decided to board ship with the majority of his companions were unharmed and his victory unsullied, and to sail for the island vouchsafed to him by divine prophecy.[...] The island at that time was called Albion; it had no inhabitants save for a few giants. ${ }^{73}$

Merlin's prophesy makes an appearance in book seven of the Historia. Merlin's prophecy is considerably longer in the Historia than in the Taliesin, making it clear that Geoffrey embellished his depiction of Merlin, but the similarities are there, mainly in the fact that Merlin/Taliesin was prophesizing the outcome of a battle. Likely owing to Geoffrey's bias against the Welsh, the most important line of the poem, which foretells the rule of the island by the Britons [Welsh], Geoffrey makes sure to contradict. The prophesy of Taliesin says:

Then will the Britons gain

Their land and their crown, And the foreigners

Will disappear. ${ }^{74}$

\footnotetext{
${ }^{72}$ Geoffrey of Monmouth, The History of the Kings of Britain, trans. Neil Wright, ed. Michael D. Reeve, (Woodbridge: Boydell Press, 2009), 6-26.

${ }^{73}$ Ibid., 26.

${ }^{74}$ The Mabinogi and Other Medieval Welsh Tales, 181.
} 
Geoffrey, on the other hand says: "The Welsh, unworthy successors to the noble Britons, never again recovered mastery over the whole island, but, squabbling pettily amongst themselves and sometimes with the Saxons, kept constantly massacring the foreigners or each other." ${ }^{.75}$ The juxtaposition between what Geoffrey used in the Historia and what he left out shows that Geoffrey both admired some of the elements of Welsh storytelling, but refused to honor the idea that the Welsh could possibly rule over the island again.

Like Geoffrey, Walter Map showed an affinity for Celtic storytelling, but a distaste for Welsh politics. Walter writes "Of King Herla" in a traditionally Welsh way. Joshua Byron Smith points out that because King Herla is what he believes to be a revision of the story of King Herlething in distinctio 4 of De Nugis Curialium, hence, "Of King Herla" "is more a creation of Walter's own." ${ }^{, 76}$ Smith acknowledges that many literary scholars believe that Walter heard the story while a child, but he also believes that this is unlikely. The truth is likely a mix of these two opinions - Walter may have heard many Welsh tales with the same fantastical elements as a child, and because these tales sparked his imagination, he decided to write in the same custom. He is not necessarily writing down stories he heard as a child, but recreating elements he may have heard. Smith also relates the story to a continental Celtic story of the Wild Hunt. Smith writes "Herla's spectral household has long been identified as a Welsh reflex of a widespread

\footnotetext{
${ }^{75}$ Geoffrey of Monmouth, The History of the Kings of Britain, 280.

${ }^{76}$ Joshua Byron Smith, Walter Map and the Matter of Britain (Philadelphia: University of Pennsylvania Press, 2017), 90.
} 
European folktale usually called "The Wild Hunt" or "The Ghostly Hunt."" While this is likely the case, it is also important not to overlook some of the similarities found between the story of Herla and Welsh stories, particularly the story of Pwyll's visit to Annwfn. In the story, Pwyll is hunting with his dogs when they kill a white stag. Soon they are approached and rebuked by Arawn the king of Annwfn, a kingdom of the otherworld. Pwyll agrees to make up for the killing of the white stag by going to live in Annwfn as Arawn for one year and a day, while Arawn lives as Pwyll in his kingdom. ${ }^{78}$ Both Pwyll and Herla are approached by beings from another, secret world. These other worlds are rich in wealth, food, and drink. Both stay in these worlds for a time before coming out again to try and rejoin their lives.

Another tale involving the other world is found in the Third Branch of the Mabinogi, in which Manawydan goes hunting one day and his friend Pryderi gets lost and stuck in the otherworld and has to be rescued by Rhiannon, who ends up trapped with him, stuck to a cauldron. Manawydan and Pryderi's wife Cigfa assume that they are gone forever. ${ }^{79}$ While Rhiannon and Pryderi are eventually returned to their respective spouses, they are stuck in the otherworld for what seems to be a considerable amount of time, and they were led there by an unearthly creature, in this case an all-white boar. Some aspects of the otherworld are changed in Walter's story, but the main ideas remain: time has a different meaning, mortals can go when they are invited or enticed, and the otherworld is accessible through hidden entries, and perhaps residing on another plane of

\footnotetext{
${ }^{77}$ Ibid., 89.

${ }^{78}$ The Mabinogi and Other Medieval Welsh Tales, 38.

${ }^{79}$ Ibid., 80-81.
} 
existence. ${ }^{80}$ It is likely that Walter took the stories of the Ghost Hunt and combined it with the stories of the Welsh otherworld and created his own tale. It is also possible that the continental stories of the "Great Hunt" are vestiges of continental Celtic mythology similar to the Welsh and Irish tradition. Either way, the tales could be construed as a bit of a jab towards the roaming court of Henry II. ${ }^{81}$

The literary tradition of Wales consists of poems exalting powerful and strong princes who can command armies and who exude manly virtues of valor and honor. These poets held power in such a way that they were nearly equal with the princes they served - they could create a loyal following with their words, but they could also take that following away by the same means. The story of Taliesin shows the power the Welsh gave to their storytellers, and the expected relationships they held with their kings.

The Mabinogi gives its audience a look at the mystical side of Welsh tradition. There are magicians, shapeshifting, goddesses who marry mortals, and sojourns pleasant and unpleasant into the otherworld. And while the written stories we have now were documented in the twelfth century, many scholars believe that they are considerably older, which fosters the theory that Welsh culture was one of long-standing tradition,

\footnotetext{
${ }^{80}$ The Otherworld in Welsh mythology exists in another dimension in the modern sense. Entry is not difficult--usually an animal of the Otherworld leads a mortal to an entrance. They are transported to a completely different realm, without any trace of their earthly habitat. This is evident in many of the stories in the Mabinogi, especially in The Mabinogi and Other Medieval Welsh Tales, 35.

${ }^{81}$ Joshua Byron Smith talks about both the comparison of "The Tale of King Herla" and "Herlething" in De Nugis Curialis, claiming that they are the same tale, altered. He proposes that Herlething is from The Wild

Hunt, which was a common story of the continent at the time. He also notes that Walter Map was infatuated with Welsh story-telling and that while "The Tale of King Herla" was likely from his imagination, it could have been influenced by both Welsh and continental stories. Smith, Walter Map and the Matter of Britain, $89,93$.
} 
reaching back into the misty past. Ultimately, these stories make impacts on others outside of Pura Wallia. Geoffrey of Monmouth and Walter Map were both interested in the tradition of Welsh storytelling and wrote their own stories to reflect what they may have heard as children, but with the bias they would have had as sons of Marcher lords. Both men were also clearly dissatisfied with the state of the English ruling class and had other agendas in their writing than to simply bring forward nostalgic stories from their childhood.

Wales in the twelfth and thirteenth centuries was a violent place. Between the conquests of the Anglo-Normans and English, the Vikings, Flemish, and Hiberno Norse, Wales was under regular attack from the outside. Wales was also under attack from the inside - princes pillaged and burned, exiling, castrating, and blinding each other in an attempt to be the sole ruler over larger areas of land. The near anarchic atmosphere was a difficult and occasionally terrifying state in which to live. In short, medieval Wales was a dangerous and disharmonic place. Despite the near constant state of warfare and the difficulty in any lasting political unification, the Welsh had a strong bond of shared cultural experience and social contract. This bond was made evident through the poetic and storytelling traditions that had been held in importance for generations. 


\section{Chapter 3}

\section{Where 'Chaos' Reigned: The Political Instability of the Region of Wales}

The Welsh, unworthy successors to the noble Britons, never again recovered mastery over the whole island, but, squabbling pettily amongst themselves and sometimes with the Saxons, kept constantly massacring the foreigners or each other.

--Geoffrey of Monmouth ${ }^{82}$

Gerald of Wales, Walter Map and Geoffrey of Monmouth, all three of these twelfth-century ecclesiastic authors raised in the March of Wales, agree that the Welsh were citizens of a divided region, with the majority of its male population made up of warriors. In Journey Through Wales and Description of Wales, Gerald spends time unpacking the numerous ascribed faults of the Welsh, from their apparent inability to keep promises to the practice of incest. ${ }^{83}$ Walter Map likewise refers to the Welsh as his compatriots, while also remarking that they are "wholly unfaithful to everybody," 84 and that "if in one respect they may appear kindly, in most they show themselves ill-tempered and savage." ${ }^{95}$ Geoffrey of Monmouth declares that the Welsh were those left over after the Britons' "culture ebbed," and that they were "unworthy successors to the noble Britons," "squabbling pettily amongst themselves and sometimes with the Saxons, [the Welsh] kept constantly massacring the foreigners or each other." ${ }^{\text {"6 }}$ Although these three

${ }^{82}$ Geoffrey of Monmouth, The History of the Kings of Britain, 280.

${ }^{83}$ In his Description of Wales, Gerald details the traits and inheritance of the Welsh in two books, with the second book consisting of more inflammatory remarks about the Welsh. Gerald of Wales, "Book II, Description of Wales," in Journey Through Wales/The Description of Wales, trans. Lewis Thorpe (London: Penguin Books, 1978), 255-274.

${ }^{84}$ Walter Map, De Nugis Curialium, ed. Brooke and Mynors, 183.

${ }^{85}$ Ibid., 147.

${ }^{86}$ Geoffrey of Monmouth, The History of the Kings of Britain, 280. 
men were sons of marcher lords, and their interest lay mostly with those of the English crown and church, their comments on the Welsh correlate with the Brut y Tywysogion concerning the violence that plagued the region.

The Brut y Tywysogion is a chronicle of Welsh history beginning in 682 and ending in 1282. There are two copies in existence, one is in the Bodleian Library at Oxford, while the other is kept at the National Library of Wales in Cardiff. According to the library's website, the manuscript kept in the National Library is called the Peniarth 20 version and is considered the more accurate of the two copies. Both copies are written in Welsh and survive from the fourteenth century, and both are viewable through their respective libraries. According to the National Library, the author of the Brut $y$ Tywysogion is a mystery, however Welsh sayings and a bardic format seem to indicate that it was written by a Welshman. This Welsh writer likely copied from a number of now lost annals collected from Welsh monasteries. The author seems to believe that the Welsh had descended from nobility but had since been sinful and were subsequently dealing with heavenly punishment. The Brut y Tywysogion thus makes a substantial contribution to the study of Welsh history prior to the conquest of Edward I. ${ }^{87}$

When reading the history of Wales as it is presented by the Brut y Tywysogion, it is evident the warrior culture of the poems presented in the previous chapter was prevalent in medieval Wales. ${ }^{88}$ Aristocratic families were often at war over territory,

\footnotetext{
87 “Chronical of Princes," The National Library of Wales, accessed May 29, 2020. https://www.library.wales/discover/digital-gallery/manuscripts/the-middle-ages/chronicle-of-the-

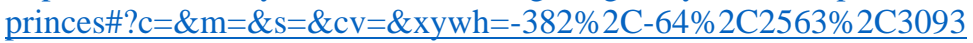

${ }^{88}$ When I refer to medieval Wales in the Brut, I am referring to the period of the eighth through the fourteenth century, which are the centuries covered by the annal. However, the majority of this chapter will
} 
committing atrocities such as kidnapping, rape, castration and blinding in order to gain power and authority. Concurrent with the internal warfare, there were external attacks from Vikings, the Franks and the Irish. By the time the Norman-English arrived in 1067, Wales was already a land in turmoil, allowing the Norman-English aristocracy to gain a foothold in and later take control of the region as a part of England.

The Welsh considered themselves the people of an independent region, united by their cultural and linguistic heritage, despite the lack of a unified government. This distinctiveness was acknowledged and honored by the Anglo-Saxons, and Wales was largely left alone until King William II began expanding the March and building castles inside the borders of Wales in the late eleventh century. Despite Norman incursions, Wales was still considered a separate region even after the defeat of Llywelyn ap Gruffudd in 1283, and did not become a part of Great Britain until many centuries later. ${ }^{89}$ This chapter discusses the internal political strife which underlay the cultural uniformity in medieval Wales, and how outside aggressors further destabilized the already fragile and fragmented political entity, eventually leading to the end of a sovereign Wales.

concern the period from 1086 through 1283 - from the beginning of the Norman conquest until the death of Llywelyn ap Gruffudd.

${ }^{89}$ For the most part, this date is acknowledged as the end of Wales as a sovereign state, but some scholars, such as David Stephenson, place the date is in the fourteenth century. It is also important to note here that Owain Glyn Dŵr orchestrated a revolt against English rule in Wales in 1415, and the inclusion of Wales into Greater Britain was a combination of slow social and political changes as well as conquest. For more on this see R.R. Davies, "Epilogue," in Age of Conquest. 


\section{Examples of Violence and Unity in the Brut y Tywysogion}

Despite their acknowledgement of a shared culture and history, both mythical and real, the divisions between ruling families and separate principalities in Wales was a regular feature of Welsh politics. These divisions created a conglomeration of small kingships that existed in a near constant state of warfare. According to the Brut $y$ Tywysogion, the instances of violence and warfare began in Wales in 728 with the battle of Carn Mountain (mynyd Carn). ${ }^{90}$ After the eighth-century battle, the Brut elaborates on one hundred and seven cases of Welsh-on-Welsh violence involving the aristocracy. Many of the cases involved fathers against sons, uncles against nephews, or disputes between brothers, and the noted violence increased significantly at the end of the eleventh century. Prior to 1066, the Brut y Tywysogion notes one record of Welsh-on-Welsh violence. This is not to say that there were rarely clashes between Welsh kings/princes earlier than 1066, but this difference in the number of recorded violent instances demonstrates a pattern of increased violence after the Norman victory at Hastings. Shortly after 1066, the number of violent clashes increased rapidly. Between 1066 and 1080 when Cardiff was built by William II, there are six instances of Welsh-on-Welsh violence, with the majority of the violence resulting from a battle begun in 1073 . The year 1073 marks the beginning of four years of battle among the Welsh princes, which included Rhys, the son of Owain, killing Bleddyn, son of Cynvyn, in what the annals refer to as "the deceit of evil-minded chieftains" near Carmarthen (the Vale of Tywi). This was then followed by another battle involving Gruffudd ap Cynan and Iago against

${ }^{90}$ Brut y Tywysogion, trans. Williams Ab Ithel, 4-5. 
men of the isle of Mona. During this attack on Mona, the men of Gwynedd killed Cynvrig ap Rhiwallon. These incidents were followed by another four battles, two killings by treachery, and a revenge killing. ${ }^{91}$ These battles occurred after the "French" it is unclear whether these are Franks, Anglo-Normans or Flemish- had attacked both Dyved and Ceredigion and "Bangor was laid waste by the Pagans." 92 This group of battles recorded in the Brut shows the characteristic of Welsh violence as seen by the Normans - the fighting was started by one incident and propelled forward by Welsh princes with a sense of honor to defend. Also noted in this four-year span are the attacks by outside forces, which supply the Welsh princes with a common enemy but also add to the internal turmoil. Despite the frequency of violence in Wales, there are also periods in which little or no strife occurs at all. ${ }^{93}$

The Norman victory at the Battle of Hastings is noted in the Brut, which describes William the Bastard (later Conqueror) as a defender of "the kingdoms of England in a great battle," and that he had an "invincible hand" and a "most noble army."94 After this victory by the Normans, the main aggressor appears in the Brut as the "Frienes" (also written as Ffreinc), or the Franks $;{ }^{95}$ the Brut chronicles further violence as the NormanEnglish began to encroach into Welsh land. ${ }^{96}$ The evidence from the Brut suggests the

\footnotetext{
91 Ibid., 49-51.

92 Ibid., 47.

93 The attacks by the pagans as put in the Brut are likely to be attacks by Scandinavians.

${ }^{94}$ Brut y Tywysogion, 47.

95 The Friene or Ffreinc were treated differently in the annals from the Normans, who bear the name Normanyeit; the Flemish are Fflemisset. It is likely that the Friene and Ffreincs were the Franks, rather than the Anglo-Normans. The Franks in this instance may represent the people who were living in modern-day France, but not Normandy, or Belgium.

96 These are counted from the beginning to the end of the Brut and do not include Welsh violence against the English or Franks but do include times when the Welsh would fight against each other on the side of the English. All events counted are taken directly from the Brut. Brut y Tywysogion, 4-373.
} 
escalation in fighting coincided with the increase of Norman and later English involvement in Welsh politics, and the loss of land to the Norman-English settlers beginning in the late eleventh century. While this elevation may be little more than a coincidence, the consequence of a later writer for the Brut, or even signal a newfound importance to detailing the disputes between the Welsh princes, there is no denying an inflation in recorded violence. It was most likely a combination of factors. According to Stephenson, the increase of violence recorded in the Brut is not imaginary; rather the introduction of the Normans brought a new flashpoint for enmity into Welsh society, and the Normans played the part of both ally and antagonist. The Welsh princes now had new allies/enemies to fight with and against, thereby exacerbating the already virulent situation. ${ }^{97}$

In 1108, Iowerth, son of Bleddyn from Powys, was released from imprisonment by Henry I, who had captured him during an uprising in 1100. Upon his release, Iowerth became allied to Henry I, and fought with Cadwgan against his nephews Madog and Owain. ${ }^{98}$ Madog and Owain begin pillaging the countryside in Wales. Iowerth enlisted the help of other Welsh princes, and Henry I gave money to Cadwgan in order to aide his defense against Owain and Madog. Madog retaliated against Iowerth, whom he burned alive in his own home. Owing to the tragedy of Iowerth's death and in acknowledgement of Cadwgan's loyalty to the English crown, Henry I gave Cadwgan the land formerly belonging to Iowerth. Madog, however, continued to pillage and burn before he was

\footnotetext{
${ }^{97}$ Stephenson, Medieval Wales c. 1050-1332: Centuries of Ambiguity, 9.

${ }^{98}$ Brut y Tywysogion, 97-111.
} 
found and blinded by Maredudd in 1110. ${ }^{99}$ Maredudd, Cadwgan, Iowerth and Madog were all princes of Powys. This series of events seems to have begun with a Welsh uprising in Powys in 1100 and was made worse by the alliance between Iowerth and Madog. It can be surmised that Madog felt Iowerth was no longer a worthy prince of Powys after his conditional release from prison and his subsequent alliance with Henry. The hostilities between the Welsh princes were compounded when Iowerth sent Madog and Owain a letter explaining that Iowerth and Cadwgan were commanded to have no more dealings with Madog and Owian, and that the latter two should leave Wales upon pain of imprisonment or death. ${ }^{100}$

The Welsh were not always violent in their dealings together. The NormanEnglish threat gave the Welsh a new and common enemy. Instead of in-fighting, the Welsh princes combined forces to attack Norman castles and later settlements, as well as waged war against Henry I and his Angevin descendants. For example in 1094, Uchtrud, Howel and "many other chieftains of the family of Cadagon" together stormed, razed and looted Pembroke Castle. ${ }^{101}$ The earlier mentioned fight resulting in the burning death of Iowerth was also started by the Welsh princes of Powys banding together in 1100 against Henry I. Later, in 1118, Henry I raised an army against the Welsh princes in northern and central Wales, who "resolved to guard the boundaries of their own countries,"102 in effect stopping any fighting amongst themselves in favor of defending Wales from the English

\footnotetext{
${ }^{99}$ Ibid., 107-111.

${ }^{100}$ Brut y Tywysogion, 99.

${ }^{101}$ As I later state, according to Max Lieberman, Pembroke Castle was attacked by the Welsh many times, but remained in Anglo-Norman control. This is one of the few mentions of Pembroke Castle in the Brut. Ibid., 59.

102 Ibid., 149.
} 
monarch. In this case, Henry I was forced to leave Wales because he had been shot in the leg with an arrow, narrowly escaping death. ${ }^{103}$ The development of the March of Wales by the Norman-English proved to be a larger ongoing problem for the Welsh, as it slowly led to loss of land and created more opportunities for violence, while also encouraging Wales to emulate the Norman style of warfare.

\section{The March of Wales and Norman Castle Building}

Stephenson calls the March of Wales "the single most significant element in the history of Wales in this period." 104 According to Max Lieberman, "the medieval march was a unique part of the political geography of Britain." ${ }^{105}$ While the Marches were formally established by the Norman-English, prior to 1066 the border between what was Anglo-Saxon England and Wales had been firmly fixed at Offa's Dyke. ${ }^{106}$ The AngloNorman March of Wales slowly crossed this border and took the place of lands that had been exclusively Welsh territory, and created a new space that was not recognized as either Welsh or English. Instead, these new lands constituted the March of Wales, and were treated as separate by the Welsh, the Marcher lords, and the English. ${ }^{107}$

The Norman creation of the March began in the south with castle building, which the Welsh strongly opposed. ${ }^{108}$ Despite Welsh anger toward the Norman incursions,

\footnotetext{
103 Ibid., 147-151.

104 "This period" refers to the twelfth century. Ibid., 10.

105 Max Lieberman, The March of Wales 1067-1300: A Borderland of Medieval Britain, (Cardiff: University of Wales Press, 2019), 5.

${ }^{106}$ R.R. Davies, Age of Conquest: Wales, 1063-1415. (Oxford: Oxford University Press, 2000), 2.

107 R.R. Davies, "The Identity of 'Wales' in the Thirteenth Century," 60.

${ }^{108}$ For a map of the progression of the Welsh March and Norman castles, please see the appendices on page 93 through 98.
} 
Norman lords continued to build castles, and warfare resulted. The construction of Cardiff Castle began in $1080,{ }^{109}$ and is followed fourteen years later by the building of Rhyd y Gors Castle (now Carmarthen Castle), roughly sixty-six miles to the northwest of Cardiff. ${ }^{110}$ Rhyd y Gors was commissioned by King William II according to the Brut, following an apparent first uprising by the Welsh in 1092. William Rufus had gone to Normandy, and the Welsh took this opportunity to destroy the castles at Ceredigion and Dyved. ${ }^{111}$ These uprisings indicate that by 1092, the Normans had begun aggressively to encroach far into southern Wales (see map on page 93). Norman castles and settlements cut into the arable land in Wales, leaving less viable territory for the princes and their people. These events together led to an increase in violence in Wales, including Welshon-Welsh incidences.

The introduction of Norman castle-building in the southern part of Wales and the way the Norman-English waged war also inspired a change in Welsh warfare and tactics. Stephenson explains that during the thirteenth century Welsh princes began to handle rivalries differently. Instead of castrating and blinding or killing outright, many Welsh princes were willing to let their rivals go free and to keep some of their land. ${ }^{112}$ Indeed, in the Brut, there are significantly less blindings and castrations after Llywelyn ap Cadwallon was blinded by his brothers in $1186 .{ }^{113}$ This is the last documented case of blinding recorded in the Brut. After this point there are also far more instances of

\footnotetext{
${ }^{109}$ Brut y Tywysogion, 51.

${ }^{110}$ This is an estimate via Google maps and is the shortest distance currently by car along the M4.

${ }^{111}$ Brut y Tywysogion, 59.

${ }^{112}$ Stephenson, "The Age of the Prince: Shifting Political Cultures and Structures," in Medieval Wales 1050$1332,54$.

${ }^{113}$ Brut y Tywysogion, 233-235.
} 
prisoner-taking and castle-building by the Welsh, as well as peace agreements made by feuding Welsh princes. While cases of violence and war were still very much a reality in Wales, feuding and military tactics changed considerably from the twelfth century on.

\section{Land Partitioning, Lineage, and Military Power}

According to Davies, military might, land partitioning, and inheritance were common causes for violence in medieval Wales. Davies tells us that succession "was determined by military prowess and personal mastery as well as by lineage."114 When a king died, his son did not automatically gain the title of king or prince. Instead, his uncles, cousins or even new dynasties tried to take power. Davies points out that the Welsh as a whole were known for their military prowess, calling their ability "wellrecognized" by Anglo-Norman kings and lords, and were often used to enlarge their $\operatorname{armies}^{115}$ even during the age of Norman conquest in Wales.

While a strong military force is beneficial during times of war, in times of peace many of the young warriors had to be kept occupied lest they become a disruptive force in the Welsh kingdoms. According to Davies, this necessity led kings to enlist young male warriors as body guards, heightening tensions already present in warrior culture and the competitive nature of Welsh kingship. ${ }^{116}$ Kings would surround themselves with body guards in order to look more important, as well as protect themselves against the possibility of attack. Bodyguards further added to and propagandized military might;

\footnotetext{
114 Davies, "Native Wales 1063-1172," 59.

115 Ibid., 66.

116 Ibid., 66-67.
} 
Davies notes that the courts were "bound to have a prominent military aspect."117 The personal bodyguard and military function of the court reflected the strong warrior motifs present in the poetry, which was fixated on warrior culture and the heroic past.

The issue of inheritance also came into play with the partitioning of inherited territories by the sons of kings. Many kings had multiple sons, and while younger sons were unlikely to inherit the title of king or prince, they were still often given land. As Davies points out, this further partitioned land between brothers, causing a loss of ruling territory for the older brother. The issue of land partitioning between brothers paired with the Welsh laws of legitimacy and the practice of polygamy by the princes ${ }^{118}$ helped to destabilize the authority and power between brothers and cousins. This many times led to warfare between princes in different regions. For example, in 1121, Gruffudd ap Maredudd killed his cousin Ithel, son of Rhirid, and Cadwallon killed his three uncles. ${ }^{119}$ All of these men were princes of Deheuberth, and the fights were most likely over territory. Just the year before in Powys and Meirionydd, there was a battle between several princes at the death of Einon. ${ }^{120}$ All of the princes felt they were entitled to the land, despite the fact that Einon had left it to his brother Maredudd. Fighting broke out and several princes banded together and marched their armies on Powys in order to claim the land. The initial fighting involved Maredudd ap Bleddyn, who was the uncle of Maredudd, Einon, Cadwalader, and Owain. It did not end in 1121, being followed by

\footnotetext{
${ }^{117}$ Ibid., 62.

118 Ibid., 71.

${ }^{119}$ Brut y Tywysogion, 153.

${ }^{120}$ It is unclear if Einon was a prince or if he was a war-chief. The Brut y Tywysogion calls him "the son of Cadwgan," but does not mention any formal title. Ibid., 151.
} 
three revenge killings involving those princes and their families in 1122 . The entire twoyear affair ended with a fight between Morgan and Maredudd, both sons of Cadwgan, in which Morgan killed his brother Maredudd. Cadwgan was one of the original brothers of Einon who was not initially fighting over Powys. However, the fighting had reached so far out into the family, that extended family who had little involvement at the start became deeply involved in the fighting. These two-years of familial violence show the difficulties that developed over inheritance claims between family members.

\section{Llywelyn ap Iowerth or Llywelyn the Great}

The latter half of the twelfth century was a particularly violent period in Wales. In the early 1190s, Llywelyn ap Iowerth made alliances with his cousins and sought to gain control over all of Gwynedd. At the time, Gwynedd was fractured into three parts between Dafydd ab Owain, Rhodri ab Owain, and the two sons of Cynan ab Owain, Maredudd and Gruffudd. ${ }^{121}$ Maredudd and Gruffudd were the cousins of Llywelyn, who formed an alliance with them in order to push Dafydd out of Powys, whose land then went to Llywelyn. At some point Rhodri died and Maredudd and Gruffudd inherited his land. ${ }^{122}$ By the end of the twelfth century, Gwenwynwyn of Powys was Llywelyn's main adversary, and Llywelyn had put himself in a position to expand south and east from Gwynedd. The two were forced into a peace treaty by the Welsh clergy in $1202,{ }^{123}$ but it would not last long. In 1207, Gwenwynwyn was captured by King John, and Llywelyn

\footnotetext{
${ }^{121}$ Kari Maund, "Llywelyn ap Iorwerth," in The Welsh Kings: Warriors, Warlords and Princes, (Stroud: Tempus Publishing, 2006), 187.

${ }^{122}$ Ibid.

${ }^{123}$ Brut y Tywysogion, 257-259.
} 
seized the land belonging to him. ${ }^{124}$ Two years later John returned the confiscated land to Gwenwynwyn upon his release from imprisonment. Gwenwynwyn then made peace with the English king, sparking an open revolt by the other Welsh princes, led by Llywelyn. By the time of his revolts in 1216, however, Llywelyn had held control over all of Gwenydd and been married for seven years to Joanna, the daughter of King John. ${ }^{125}$ The marriage to Joanna had helped Llywelyn to gain royal support, and gained him recognition from King John as a legitimate prince of Wales, a title newly sought after by Welsh princes in order to gain legitimacy with the crown. ${ }^{126}$ The problems arose when, later that year, Llywelyn retaliated against one of the king's allies, Rhys Gryg, who had attacked Llywelyn's allies, the sons of Gruffudd ap Rhys. Eventually King John gained the upper hand and forced Llywelyn to sue for peace, sending his own wife to the king as a hostage. ${ }^{127}$ This did not end Llywelyn's efforts. Instead, Llywelyn was able to raise an army of Welshmen against King John, and further cement his power in Wales. John died in October of 1216, leaving Llywelyn to negotiate with the new king, Henry III. Llywelyn tied himself to his Marcher neighbors through the marriages of his daughters and he expelled Gwenwynwyn for the last time, and by 1225 had secured himself as ruler of Wales. ${ }^{128}$ When Llywelyn passed away in 1240 , he had established himself in a

\footnotetext{
${ }^{124}$ Brut y Tywysogion, 263.

125 Maund, "Llywelyn ap Iorwerth," 188.

${ }^{126}$ Stephenson explains the English incursions into Welsh politics when it directly affected the English (Anglo-Norman) interests in Wales and Ireland. He refers to the English (Anglo-Norman) kingdom as a more powerful neighboring kingdom. The Anglo-Norman kings frequently involved themselves in Welsh politics, and Stephenson implies that the Welsh both relied on and shied away from Anglo-Norman interventions depending on how it would benefit them at the time. Stephenson, Medieval Wales c. 1050$1332,85-91$.

${ }^{127}$ Ibid., 192, 195. Brut y Tywysogion, 269.

${ }^{128}$ Maund, "Llywelyn ap Iorwerth," 196.
} 
position of power that had not been gained by a Welsh ruler since the Norman conquest began, and he was well-respected and thought highly of by everyone he had dealings with throughout his lifetime. ${ }^{129}$

Llywelyn's rise to power over Gwynedd and his recognition by the English crown were major accomplishments, but Llywelyn's leadership was still dependent on a careful balance between English and Welsh power. Llywelyn had to balance his loyalty to the English king, who could give him outside acknowledgment and military support, with loyalty to his fellow Welshmen. Llywelyn's balancing act shows the position the Welsh princes were put in when they worked their way up in power. The intrusion of the English king into Welsh politics added an extra element into the situation that could have worked out differently in some respects. When King John captured and imprisoned Gwenwynwyn, Llywelyn was able to steal his land. Llywelyn could have held it for longer and perhaps cemented his authority over all of Wales if John had not given Gwenwynwyn his land back upon release. Despite or because of the involvement of John and Henry III, however, Llywelyn was able to take control over considerable land in Wales and create a precedent for other Welsh princes to strive for. Llywelyn was fortunate in his rise to power, and according to Kari Maund was "a gifted diplomat" with "remarkable charisma." ${ }^{130}$ Llywelyn's effective leadership came too late to establish Wales as a sovereign state. His grandson, Llywelyn ap Gruffudd, was the last prince of Wales.

\footnotetext{
${ }^{129}$ Ibid., 201.

${ }^{130}$ Maund, "Llywelyn ap Iorwerth," 202.
} 


\section{Llywelyn ap Gruffudd and the Ending of Wales}

It can be argued that Llywelyn ap Gruffudd was the last prince of Wales, with his reign lasting from 1246 to his death in $1282 .{ }^{131}$ Llywelyn's reign was marked by the Edwardian conquest of Wales, which began in 1277 as King Edward I pushed the rebuilding of castles and settlements farther into what was traditionally Welsh sovereign lands. ${ }^{132}$ Llywelyn came into power in Gwynedd after the death of his father and uncles, without the power his grandfather had claimed for himself. However, Llywelyn managed to force the English out of Wales and earned loyalty from the majority of the native Welsh lords. ${ }^{133}$ Llywelyn reached the apex of his career in 1267, but afterward suffered a steady decline in power. By 1274, Llywelyn was losing his support from the other princes, and in 1275 Llywelyn fell out with King Edward when he could not gather the other Welsh princes to meet with Edward. ${ }^{134}$ Without the support of the other Welsh princes or of the king, Llywelyn could no longer keep his hold on Wales. Llywelyn was relieved of his head in 1282, a consequence of the continuing rebellion. After the death of Llywelyn, Edward reportedly held a round-table and referred to himself as Arthur. Castle-building in Wales was commenced, and Wales was officially subjugated to the English crown. ${ }^{135}$ While Llywelyn ap Gruffudd was the last successful prince of Wales, the rebellion continued with Dafydd ap Gruffudd, Llywelyn's brother and successor in

\footnotetext{
${ }^{131}$ Most scholars agree that the deaths of Llywelyn ap Gruffudd and his brother Dafydd in 1283 mark the end of Wales as a sovereign place, however David Stephenson puts the date into the 1330s, citing other relevant events in the fight for control of Wales. Stephenson, Medieval Wales c. 1050-, 153.

${ }^{132}$ Kari Maund, "Llywelyn ap Gruffudd," in The Welsh Kings, 223.

133 Maund, "Llywelyn ap Gruffudd," 207.

${ }^{134}$ Brut y Tywysogion, 363.

135 Ibid., 121.
} 
Gwynedd. However, Dafydd lacked any support. Edward captured Dafydd and after a trial in Shrewsbury he was convicted of treason. Dafydd was hanged, drawn, and quartered on October 2, 1283; he was the "last native prince of Gwynedd."136 The long struggle for a Wales ruled by the Welsh and independently from the English was at an end. While some Welsh institutional traditions persisted, including their independent law code, into the sixteenth century, Wales was now a part of what would later be called the kingdom of Greater Britain. This does not mean that the Welsh were subdued; in fact, uprisings continued for centuries, one of the most notable being the rise of Owain Glyndŵr in the fifteenth century. However, Wales would not be separate from England again.

In the scholarly conversation about Welsh violence, R.R. Davies brings up the problem of dominance and authority in Wales. Davies states that "in the absence of effective central authority, each must dominate or be dominated." ${ }^{137}$ Violence in Wales was a symptom of the lack of a clear initial leadership and the addition of outside forces. Leaders in Wales were not able to gain control until well after the Norman-English had established themselves as the lords over the region. Indeed, the majority of the recorded violence in Wales was acknowledged by the Brut after the Norman incursions. This gives the impression that the violence in Wales was largely a symptom of the Norman invasions and the loss of land to the Marches. The problem with this theory, however, is that while the annals do not record much earlier violence, poetry from as early as the

\footnotetext{
${ }^{136}$ Maund, "Llywelyn ap Gruffudd," 229.

${ }^{137}$ Davies, "Native Wales: 1063-1172,"
} 
sixth century details a warrior culture which fought Anglo-Saxons in Northumbria before moving into the western part of the island. The customs of inheritance and princely retinues were also indicative of a warrior culture owing to the fact that military prowess had the same value as family status. In order to be a prince, one must both be born into a high-ranking family and retain a retinue of warriors. The weaknesses of the Brut in the Welsh narrative are the bias of the scribe and the fact that it is incomplete. While the scribe is true to many events and details, the Brut can not always be relied upon for a complete or faithful representation of all the events and customs in medieval Wales. Instead, it is imperative to interpret the Brut alongside contemporary poetry and literature. The violence described in the Brut is likely to be real, but the scribe tends to lean towards the premise that the Welsh are incapable of self-government. ${ }^{138}$ At times the scribe stressed the "goodness" of an Anglo-Norman king (for example William the Conqueror), and also occasionally left out information. In order to gain a clearer understanding of customs and society in medieval Wales, it is important to read the poetry and literature alongside the Brut, which gives the reader a clearer sense of the contemporary social implications demonstrated in the events it records.

It is interesting to note that the two most powerful Welsh leaders came out of Gwenydd, the last region of Wales to come under the rule of England. These leaders also came to power when Wales was losing its status as separate from England. The involvement of Norman and English kings likely disrupted and altered many other chances for the Welsh princes to consolidate control over all of Wales in a time when

${ }^{138}$ National Library of Wales, "Brut y Tywysogion." 
warfare and methods of rule were changing. The Welsh had just begun, over the prior century, to use stone castles and negotiation as tools of war. However, the competitive and unorganized nature of the Welsh courts, violent family rivalries, and a mass of small principalities allowed for the Norman and English kings to disrupt and then slowly conquer the Welsh by using their own divisions against them. Whether the Brut records all early instances of Welsh-on-Welsh violence, it is clear that the Norman-English kings involved themselves heavily in Welsh politics and were able to undermine any attempt at cooperation between the Welsh princes. 


\section{Chapter 4 \\ The Norman Colonization of Wales}

It must always be borne in mind that the Welsh are not being enervated by daily toil, they are not crushed and dispirited by slavery, they are not being maltreated by unjust taskmasters. They still carry their heads high and are prompt to avenge injuries. They are ready to take up arms and to rebel, and they will defend their country with the utmost courage.

$$
\text { -Gerald of Wales }{ }^{139}
$$

The Norman conquest of Wales began two decades after the battle of Hastings in 1066. William the Conqueror (William I) created the first March lordship in Wales in order to fortify his borders against the Welsh marauders. In the three centuries that followed, the march grew as the Normans slowly colonized Wales. The colonization of Wales by the Anglo-Normans was part of a larger process of colonization across Europe during the High Middle Ages. ${ }^{140}$ Anglo-Norman lords not only colonized Wales, Scotland, and Ireland, but the Normans also moved into other areas of Europe. There are many similarities between early modern colonialism and medieval colonialism; however, despite parallels, authors such as Robert Bartlett argue that colonization during the Middle Ages had distinctive features. Generally, Bartlett refers to this behavior in terms of an aristocratic diaspora, in which members of the warrior class spread outwards from

\footnotetext{
${ }^{139}$ Gerald of Wales, Journey Through Wales/The Description of Wales, trans. Thorpe, 270.

${ }^{140}$ For the purpose of this thesis, I am using the Stanford Encyclopedia of Philosophy definition of colonialism: "a practice of domination, which involves the subjugation of one people to another," As well as the following explanation of imperialism: "draws attention to the way one country exercises control over another, whether through settlement, sovereignty, or indirect mechanisms of control." ${ }^{40}$ This basic definition of colonialism, while specifically pertaining to the mass colonization by Europe in the early modern period and later, also encompasses the colonization of Ireland, Scotland and Wales by the AngloNormans in the High Middle Ages. Margaret Khon and Kavita Reddy, "Colonialism," The Stanford Encyclopedia of Philosophy, ed. Edward N. Zalta (Fall 2017 edition).
} 
western and central Europe and into frontier regions. The subject of this chapter is the colonization of Wales, which left the region subjugated by the Anglo-Normans (later English) in the High Middle Ages.

The process of colonization in Wales is far more complicated than the mere subjugation of the Welsh. The process was slow, and the Welsh both influenced and were influenced by their colonizers. The result was the March, which was neither Welsh nor English; it became its own region. The March of Wales began as a reference to the border region between the Saxon kingdom of Mercia and the Welsh region of Powys, which was accentuated by Offa's Dyke, and is noted in the Domesday Book of $1086 .{ }^{141}$ As William the Conqueror and later his son, William Rufus (William II) became comfortable with their rule over the rest of the island, they turned their focus to the borders along Offa's Dyke and into Wales. The March was increased slowly as Norman lords were issued land by the king of England, and built castles, expanding their territories further into Wales. ${ }^{142}$ Lieberman points out that the purpose of the March began as border fortification, run by trusted aristocrats, which soon turned to a means of conquest. William the Conqueror established three earldoms on the border with Wales during the late twelfth century, and as a way to ensure border protection without his presence, allowed the earls freedom of rule and raiding into Wales. By 1086, these earls began their own conquests into Welsh territory, in order to slowly expand their land holdings, thus beginning the Norman conquest of Wales. ${ }^{143}$ As the Welsh raided the Marches and fought against the Marcher

\footnotetext{
${ }^{141}$ Lieberman, The March of Wales, 1.

142 The maps in Appendix A illustrate the spread of the March, both by territory and by castles. Ibid., 15

143 Ibid., 22.
} 
lords, Anglo-Norman kings and the Marcher lords found reason to continue the expansion of the March.

The colonization of Wales appears different from modern colonial enterprises to historians such as Bartlett owing to the fact that the political structures of the Middle Ages were still forming, and the new colonies were an extension of land already owned by the colonizers. Rather than creating colonies in a modern sense, Bartlett explains that groups such as the Normans expanded their territory. Newly conquered regions were homogenized into the Latin Christian model of European culture. For the most part, these expanded territories were not methodically exploited for resources in the manner of early modern colonists because they were considered a full and permanent addition to the originating region. ${ }^{144}$ It is also important to note here that nationalism in the modern sense of the word would not yet exist for several centuries. Davies explains that the notion of nationality in the Middle Ages was largely a product of military might and localized loyalties. Kings and princes could foster a sense of national pride, and as Davies notes, this national thinking under Edward I is what ended the sovereignty of Wales and Scotland. ${ }^{145}$ English nationalism, as Davies sees it, was born in the thirteenth century, and marked the end of Wales as a sovereign state. It can be argued that the colonizing of Wales was an easy way for the Anglo-Norman kings to consolidate and make safe the

\footnotetext{
144 The main distinction that Robert Bartlett makes is that the colonizers "were not engaged in the creation of a pattern of regional subordination." Robert Bartlett, The Making of Europe: Conquest, Colonization and Cultural Change 950-1350 (Princeton: Princeton Press, 1993), 306.

${ }^{145}$ Davies refers to the reign of Edward I as the one in which 'nationalism was born,' a quote he cites from F.M. Powicke's The Thirteenth Century. R.R. Davies, "Law and National Identity in Thirteenth-Century Wales," in Welsh Society and Nationhood: Historical Essays Presented to Glanmor Williams ed. R.R. Davies, Ralph A. Griffiths, Ieuan Gwynedd Jones, and Kenneth O. Morgan (Cardiff: University of Wales Press, 1984), 51-52.
} 
borders of England. That said, the conquest of Wales by the Normans was unwanted and fought against vehemently by the Welsh, who considered themselves a united people, with a shared history, culture, and legal tradition. The fight was bitter and long, lasting three centuries before Edward I took control over Wales and the March in 1284.

As we have seen, Welsh literature/poetry was both a product of and exhorted Welsh princes' tendency towards violence and need for literary recognition. Welsh literature held a place of importance in the politics of the Anglo-Norman conquest; it encouraged princes to fight back against the Anglo-Norman lords in the March. Welsh tales influenced medieval literature through the writings of Gerald of Wales, Geoffrey of Monmouth, and Walter Map. Gerald of Wales was a conquest writer, who wrote of his travels through Wales and his thoughts on the Welsh, while Geoffrey of Monmouth and Walter Map took Welsh tales and reimagined them for a wider English audience. The literature penned by these three iconic authors allowed for them to freely critique the English court and comment on their dual heritage. While all three have clearly written critical opinions on the Welsh, they also expressed a critique on the courts of the Angevin kings, which are perhaps less outwardly apparent but also made plain when reading the texts closely. The Welsh method of story-telling and some of their specific tales, specifically present in the works of Map and Geoffrey, soon moved beyond the English courts and into a greater European audience. For example, the Welsh tales of King Arthur and Merlin became widely popular across Europe throughout the Middle Ages, and still resonate with modern audiences. 


\section{Wales and the Welsh}

Sometime around 410 Rome left the Britons to fend for themselves. According to Neil Christie in The Fall of the Western Roman Empire, after Rome pulled back from the island, Britain returned to a nearly iron-age landscape, complete with war lords and invasions of Saxons (as well as Angles, Jutes, and Frisians). Christie explains that "it may not have been total chaos, but with a possible 13 'kingdoms' (many of these compact units in Wales, in particular) established by the sixth century - facing by then an equally fragmented 'Anglo-Saxon' eastern England - there was more chaos than cohesion."146 Christie later points out that in the wake of the arrival of the pagan Saxons, western Briton managed to stay mostly Christian and developed a culture which included the church, but that the region was rife with political struggles. This area developed separately from the rest of Britain, maintaining a traditional Celtic culture rather than an Anglo-Saxon culture, and the Anglo-Saxon aristocracy respected the burgeoning region as politically independent. ${ }^{147}$

As the rest of the island became Anglo-Saxon, the Britons in the western part of the island became Welsh. According to Davies, "in spite of all its divisions, Wales had an identity of its own and so did its people," and "in the writs of the first century of Norman rule, the Welsh are invariably greeted as one people and Wales is referred to as one

\footnotetext{
${ }^{146}$ Neil Christie, The Fall of the Western Roman Empire: An Archaeological and Historical Perspective (New York: Bloomsbury Academic, 2011), 212.

${ }^{147}$ The Welsh/British poem The Gododdin was composed during the sixth-century Anglo-Saxon invasions - it is thought to be a eulogy to the fallen Bretons in a battle between the Anglo-Saxons and the British. ${ }^{147}$ The early poems by Aneirin and Taliesin are the earliest representations of the literary heritage of Wales, establishing a tradition of immortalizing warriors in songs and tales. These poems shed light on the battle for the island of Britain and connect the Welsh to their British heritage, and to the fight against the AngloSaxon invaders.
} 
country." 148 The word 'country' overstates the political reality, however the sentiments were that of pride of place and origin - the Welsh people identified themselves and were identified by others as a separate group, and the land of Wales as a separate place, with a border at Offa's Dyke. ${ }^{149}$ According to Davies, "the Welsh for their part were equally convinced, and indeed protective, of their identity as a people." ${ }^{150}$ Offa's Dyke demarcated the eastern border of Welsh territory and the western border of the territory belonging to the Anglo-Saxons, and it was held, at least in theory, as an acknowledged border between peoples. The separation between what was Welsh territory and what was Anglo-Saxon territory had been acknowledged by the time the Normans had conquered the Saxons. Also relevant was the border relations between the Welsh and the AngloSaxons - according to C.P. Lewis, the Welsh kept their status as a separate people despite working on Anglo-Saxon farms, living on the eastern edge of the border, and even farming land as tenants to Anglo-Saxon owners. ${ }^{151}$ While the border region was not a place of constant peace, the border between Wales and Anglo-Saxon England was stable and nominally respected by both the Welsh and the Anglo-Saxons.

Geography played a significant part in the political map of Wales in the Middle Ages, as Stephenson explains in his book Medieval Wales c.1050-1332: Centuries of Ambiguity. The fact that Wales is mountainous, with little arable land and many large rivers, creates a problem for effective communication, and makes rule by a single leader

\footnotetext{
148 Davies, Age of Conquest: Wales, 1063-1415, 15.

149 Ibid., 2.

${ }^{150}$ Davies, "The Identity of "Wales' in the Thirteenth Century," 49.

${ }^{151}$ C.P. Lewis, "Welsh Territories and Welsh Identities in Late Anglo-Saxon England," in Britons in Anglo-Saxon England, ed. Nick Higham (Woodbridge: Boydell Press, 2007), 133.
} 
in a centralized location difficult. ${ }^{152}$ Despite the difficulty of geography, boundaries between principalities within Wales tended to shift over the course of reigns and dynasties as kings fought each other for land and power. According to Stephenson, many of the kings were often mobile and traveled with their retinue throughout their territory, raiding in adjacent areas. ${ }^{153}$ Despite their frequent raiding and marauding Welsh kings retained familial and cultural ties with their fellow monarchs, and according to Davies, their distinct culture was as notable as their political disjunction. ${ }^{154}$ Owing to the behavior of its kings (later princes), Wales was seen by the Normans as 'barbaric' and 'uncivilized' in many respects; however, the Welsh were not as out of touch with the rest of Europe as one might suppose. Welshmen attended university in Oxford and Paris, and poets sometimes reflected "access to imported luxuries: [exemplified in] the presence on the tables of the poets' patrons of wine and exotic delicacies like oranges, ginger, sugar and cinnamon. ${ }^{" 155}$ Most importantly, the Welsh by the Middle Ages were connected to the continent via the Roman Catholic Church - Christianity had been long established in the region.

While adherence to the rites of the Catholic church is what created a civilized society for the rest of the population, a part of what made the Welsh seem barbaric to the Normans was their method of practicing Christianity - they observed a Celtic variant of the Western Roman Catholic practice, creating a pretext for Norman invasion. Bartlett

\footnotetext{
${ }^{152}$ Stephenson, Medieval Wales c. 1050-1332, 86-89.

${ }^{153}$ Ibid., 38

${ }^{154}$ Davies, "Wales and Welsh," 11.

${ }^{155}$ A.D. Carr, "Inside the Tent Looking Out: The Medieval Welsh World-View," in From Medieval to Modern Wales, 32 and 40.
} 
tells us that "the men of Frankish Europe intruded upon societies around and unlike their own," and the Welsh variant on Christianity, their lack of stone castles and their seemingly disharmonic aristocracy, paired with the direct border alongside the newly forming England, made Wales a target. ${ }^{156}$

The church was a powerful ally in the colonization of Europe during the High Middle Ages. It was a cultural unifier - the language of the church was Latin, and the traditions practiced in the western church were universal. Ecclesiastics in frontier regions such as Wales answered to the higher church and used their authority to govern the behavior of the people, possibly better than the lords in the area. According to Bartlett, "princely courts were, in the best of circumstances, culturally distinct from the surrounding society." 157 The disparity between the influence of the church and the behavior of the court could explain the circumstances in the March - those who were not aristocracy or warrior class were ruled more by the church than by the Welsh lords, allowing for open and even willing communities within the March. These communities allowed for the transmission of Welsh tales to the Anglo-Norman lords and settlers in the March.

\section{The Fight for Wales}

Davies believes that the Norman invasion into Wales was less important to William the Conqueror than securing the rest of the island. It was far more crucial for the island to be fortified against the marauding Vikings and for the disloyal Saxon lords to be

\footnotetext{
${ }^{156}$ Ibid., 23.

${ }^{157}$ Bartlett, The Making of Europe, 230
} 
deposed or their loyalty secured to the Norman king. ${ }^{158}$ That said, the Normans did make their way to Wales shortly after the conquest of 1066, and began to push the March into Welsh territory by 1087 . This movement may have been in response to an early threat against the new Norman monarchy, with one of the deciding factors for the conquest of Wales being the alliance between Welsh princes and "Saxon dissidents." 159 This implies that the main reason for Norman invasion was defensive and strategic, rather than based on greed and a desire for more land. The Brut y Tywysogion, for example, notes in 1066 that William the Conqueror "defended England" and had "a most noble army." ${ }^{160}$ The fact that the Welsh chronicler is referring to William the Conqueror as the defender of England demonstrates that he (the chronicler) and likely the Welsh recognized the presence of a border between England and Wales.

In 1081, after the battle between Gwynedd and Deheubarth at Mynydd Carn, King William travelled to St. David's in far western Wales, likely with a military retinue. Some scholars argue that when William made this military progress through Wales to St. David's, he had decided to conquer Wales. ${ }^{161}$ However, Bartlett points out that "pilgrimage centers were supposed to be at the ends of the earth," and "St. David's is on the west coast of Wales," 162 thus mitigating this argument. Davies argues that by 1087, an Anglo-Norman mint had likely been established in the area. ${ }^{163}$ By the time William had visited St. David's, Cardiff Castle had already been constructed towards the south, and

\footnotetext{
${ }^{158}$ Davies, Age of Conquest: Wales, 1063-1415, 27.

${ }^{159}$ Ibid.

${ }^{160}$ The actual date was 1087. Brut y Tywysogion, trans. Williams Ab Ithel, 89.

${ }^{161}$ Stephenson, Medieval Wales c. 1050-1332, 9.

162 Davies, Age of Conquest, 294.

${ }^{163}$ Ibid., 282.
} 
William I had established several of his lords in the south-west of Wales, now called the March. William's journey to St. David's could have been a combination of religious pilgrimage and scouting expedition for future expansion. There is, however, an inconsistency in the sources. William never conquered nor attempted to conquer Wales; Lieberman points out that the only time William ever entered Welsh territory was in his 1081 pilgrimage, which is recorded in one copy of the Brut y Tywysogion. ${ }^{164}$ In the Brut, William the Conqueror only managed to gain a foothold as far as Cardiff, and no large scale attempt at pushing into Welsh borders is recorded until $1086 .{ }^{165}$

The sentiments of the Welsh seem to have changed by 1085, when the Brut $y$ Tywysogion refers to William the Conqueror as William the Bastard. ${ }^{166}$ The change in name from William 'the Conqueror' to William 'the Bastard' is significant. 'The Bastard' was William I's cognomen before he won the battle at Hastings, when he became William 'the Conqueror'. The title of 'Conqueror' was meant as one of respect, while 'Bastard' may have reflected the idea that the chronicler, at least, did not feel that he deserved the more glorious title any longer. The chronicler's change in tone and respect towards the sovereign of England, paired with the Welsh alliance with select Saxon lords, may indicate a loss in faith, or a distaste for incursions onto Welsh soil. It is Davies who points out that in 1067, the first Norman lord, William Fitz Osborn, was established in Herefordshire, owing to the Welsh alliance with Saxon dissidents. ${ }^{167}$ The souring of the relationship between the Welsh and the Normans seems to have taken place between the

\footnotetext{
${ }^{164}$ Lieberman, The March of Wales, 22.

165 Ibid.

166 Brut y Tywysogion, 121.

${ }^{167}$ Davies, Age of Conquest: Wales, 1063-1415, 28.
} 
battle of Hastings in 1066 and the death of William in 1087. The Brut, unfortunately, provides no clues as to why the Welsh would join with the Saxon dissidents against the Normans. According to Stephenson, Bleddyn ap Cynfyn and Rhiwallon his brother had allied with Eadric Silvaticus, an English rebel, against the Normans in southwest Wales. ${ }^{168}$ It was the action of the Welsh in favor of these Saxons that Davies argues brought the Normans into Wales for the first time in 1067.

In addition to the problem of the Welsh alliance with the Saxons against the Normans in 1067, the Normans exercised another premise to claim lordship over Wales. According to Davies, Gruffudd ap Llywelyn swore an oath of fealty to Edward the Confessor in 1056, creating a client-king relationship between Edward and Gruffudd. After the Saxon strife in 1067, William I used the privilege of the oath to create the first March. Davies also remarks that the nature of the client-king relationship between the Welsh and the Saxons seems to have been more a debt of service and hostages, rather than a true king-client king relationship. ${ }^{169}$ At the time Gruffudd ap Llywelyn had made the oath to Edward, he was working towards gaining the title of king for all of Wales. However, by 1063, Gruffudd was bested in battle against Harold Godwinson, and then killed by his own men. ${ }^{170}$ This turn of events threw Wales back into chaos, and in effect negated Gruffudd ap Llywelyn's oath, as his successors had made no such oath. Regardless of what the Welsh felt about the legitimacy of the oath of Gruffudd ap

\footnotetext{
${ }^{168}$ Stephenson, Medieval Wales c. 1050-1332, 9.

${ }^{169}$ Ibid.

${ }^{170}$ Ibid., 8.
} 
Llywelyn to Edward and his descendants, and whether they felt it applied to William I, it had ceased to matter by the 1180 s.

The incursions of the Anglo-Normans were met with strong opposition, especially after the death of William I. After the formation of the March, the Welsh began to fight to preserve what was left of Wales, but also to fight more amongst themselves. As argued in an earlier chapter, the introduction of the Normans threw the Welsh further into a state of disarray and strife, adding another ally/enemy. The Marcher lords were given complete control over their new land, owing to the fact that the Norman conquering forces were now over-stretched. Giving control as well as responsibility for defense on the Welsh border to trusted lords allowed William to focus his attentions on securing his other borders. Once these Anglo-Norman lords had settled into their land, they began to attack the southeastern part of Wales in order to "neutralize it militarily." 171 The attacks led to retaliation by the Welsh in order to regain their land lost to the Anglo-Norman invaders. ${ }^{172}$ According to Davies, by the last decade of the eleventh century, the Welsh saw the Anglo-Normans as violent oppressors, who were inflicting "unbearable tyranny, injustice and [sic] oppression and violence." This violence was recorded in the poetry of Rhgyfarch, when he writes about "his sense of utter desolation that all the values of his society (law, learning, high renown, the glory of noble descent) were set at naught by them [the Normans]." ${ }^{173}$ At the same time, Welsh court poets were becoming more popular and influential in Wales - they celebrated Anglo-Norman defeats and Welsh

\footnotetext{
171 Ibid., 28.

${ }^{172}$ Stephenson, Medieval Wales c. 1050-1332, 66.

${ }^{173}$ R.R. Davies, Age of Conquest: Wales, 1063-1415, 35.
} 
victories, and encouraged the violence of the Welsh against the Anglo-Normans. ${ }^{174}$ In conjunction with the encouragement from the poets, the Welsh began to turn more of their violence away from each other and towards the lords who lived in the March. Welsh raids on Anglo-Norman holdings began to increase and become more violent.

\section{The Good, the Bad, and the Ugly: Anglo-Norman Colonialism in Wales}

According to the Normans, the Welsh fought primitively. They were known for their brutality in warfare, owing to the fact that castration, blinding, killing, and land decimation tended to be the methods the Welsh used to control problems of inheritance in the aristocracy. These methods, while effective, began to change with the introduction of Norman tactics and castle building. Stephenson notes that the Normans brought both castles and warfare which focused on taking prisoners over castration and blinding. ${ }^{175}$ Castration and blinding still occurred; the last blinding noted in the Brut took place in 1187, when "Llywelyn ap Cadwallon was unjustly seized by his brothers, and his eyes were gouged out of his head." 176 The last castration is noted in 1151, when "Owain Gwynedd deprived Cunedda ap Cadwallon, his nephew, his brother's son, of his eyes and his testicles." 177 By the middle of the twelfth century, Welsh modes of warfare were evolving into castle sieges and prisoner taking. The new warfare had been presumably learned from the Normans. However, until the reign of Llywelyn ap Gruffudd (r. 12581282), succession warfare and raiding for plunder and land continued fervently. Once

\footnotetext{
${ }^{174}$ Stephenson, Medieval Wales c. 1050-1332, 62.

175 Stephenson, Medieval Wales c. 1050-1332, 52.

${ }^{176}$ Brut y Tywysogion, 171.

${ }^{177}$ Ibid., 131.
} 
Llywelyn grew into his maturity, most raiding in Wales attempted to consolidate the Welsh into one group and expel the English. While the aristocracy in Wales worked hard to muster forces against the Anglo-Normans, the common people in and around the March were living a different experience.

The March of Wales acted as a pipeline for cultural exchange between the Welsh and Anglo-Normans. ${ }^{178}$ The introduction of the March inspired the Welsh to change to equal the Normans, in ways that could be seen as beneficial to the people who lived there. Castle building, for example, was a Norman practice that allowed border lords to control the area around the castle. Prior to the Normans, the Welsh had built in wood, much like the Saxons to the east. Not long after the Normans had begun to build their castles in the March of Wales, the Welsh began to see the benefits to having stone castles, which enabled them to better defend their territory, and gave them a place of relative security from which to fight and a more precise target to attack. The Welsh princes for the most part did not build their own castles during the beginning of the Anglo-Norman conquest, but instead utilized Norman castles they had taken. In fact, Lieberman remarks that it is easy to understand the slow and fragmentary Anglo-Norman expansion into Wales by examining a map of castles in Wales. ${ }^{179}$ The Anglo-Normans had been building castles steadily from 1067, beginning with Chepstow in Monmouthshire, and increasing to 400 castles by 1215 . A notable castle, Pembroke, was first built in 1090, at a well-protected and strategic position. Pembroke Castle remained in Anglo-Norman control throughout

\footnotetext{
${ }^{178}$ Stephenson, Medieval Wales c. 1050-1332, 76.

${ }^{179}$ Maps are located in the appendices. Lieberman, The March of Wales, 16.
} 
the Middle Ages, despite repeated attacks, the most notable during the reign of Stephen (1135-1154). ${ }^{180}$ In the middle of the twelfth century, the Brut $y$ Tywysogion records some castle-building by the Welsh. In 1148, Owain son of Gruffudd is noted as building a castle in Yale; Cadwalader son of Gruffudd built a castle near the town of Llanrhystud; and Madog son of Maredudd built Oswestry. ${ }^{181}$ These are the first recorded castles built by Welsh princes. The two with remaining ruins, Llanrhystud and Oswestry, are located on the west coast and far eastern border of central Wales, respectively.

Castles became the main target for marauding armies. Prior to the building of Cardiff in 1080, the Brut y Tywysogion frequently describes devastation of regions by armies during battles. In 1054 for example, Gruffudd son of Llywelyn fought the Saxons, severely depleting their troops, leaving few survivors. Those who survived were pursued by Gruffudd "to the fortress, which he entered, and depopulated and demolished the fortress, and burned the town." "182 An earlier entry in 1045 describes an act of revenge: "about seven score of men of the family Gruffudd fell, through the treachery of the men of the Vale of Tywi, and to avenge them, Gruffudd devastated the Vale of Tywi and Dyved." 183 In this period before the introduction of the Normans, the use of the term "taking" in reference to a region, town, or castle during battle is difficult to find. After the building of Cardiff in 1080, the vocabulary begins to change and references to the "taking

\footnotetext{
180 Ibid., 17.

${ }^{181}$ Yale (pronounced 'ya'll') no longer exists as a place in Wales, the ruins of Caer Penrhon on the central west Coast of Wales in the town of Llanrhystud may have been the castle built by Cadwalader, and Oswestry Castle is now a ruin in what is now England on the western border with central Wales. Both Llanrhystud and Oswestry can be found on Google Maps. Brut y Tywysogion, 177.

182 Ibid., 43.

183 Ibid.
} 
of" castles and loot appear more frequently, and reports of areas being devastated by invading armies slowly fade away. The majority of attacks and burnings thus seem to be directed at the castles rather than the land. ${ }^{184}$ In the year 1113, the Brut y Tywysogion details an episode of Gruffudd ap Rhys travelling the countryside, burning and taking castles, but with no mention of devastation to the towns or lands around the castles. ${ }^{185}$ Much of the warfare into the early thirteenth century became an exercise in capturing castles rather than decimating the land owned by one's adversary. ${ }^{186}$ The shift from land raiding to castle-sieges coincides with the slowly changing method of warfare mentioned above: as the Normans inched their way into Wales, they brought with them new styles of warfare and defense that were more in line with the continental European tradition, rather than what had been the norm in the British Isles since the Romans had left. ${ }^{187}$ That is not to say that the mass devastation of lands and towns no longer occasionally occurred. For instance, in 1102, Howel son of Goronwy, who had been given "the conservancy of the Vale of Tywi and Ryhd y Gors," went to the Vale of Tywi and "he collected spoils, by burning homes and laying waste to nearly all the districts, and killing many of the French who were returning home. He also raised the country on every side, and repossessed it, and the castle remained undisturbed." 188 While instances of substantial regional

\footnotetext{
184 Ibid., 120 et passim.

185 Ibid., 123.

${ }^{186}$ Stephenson, Medieval Wales c. 1050-1332, 52.

${ }^{187}$ Despite their systematic dismantling of their forts as they departed Britain in 410, the Romans left behind the skeletal remains of stone garrisons and walls throughout the country, many of which can still be seen today, for example the Roman wall in London, the Roman gates and wall at Castle Cardiff (which have been rebuilt), and of course the famous Antonine Wall and Hadrian's wall with garrisons. However, as David Stephenson notes, much of the building, including royal buildings, especially in Wales, and rural areas was made of wood rather than stone.

${ }^{188}$ Brut y Tywysogion, 77.
} 
devastation still occurred, by looking at the terminology in the Brut y Tywysogion it is possible to see a change in military behavior. The shift in vocabulary shows a correlation between the change in military tactics and the introduction of the Normans to the area. Despite the change in warfare, the Welsh poets maintained the allure of eternal recognition through poetry and kingly valor. Poets continued to compose eulogies for fallen warrior kings throughout the twelfth century. For example, in the Elegy for Madog ap Maredudd composed after his death in 1160, the poet emphasized Madog's prowess in battle, calling him:

buckler on battlefield, and in brave deeds:

A tumult like flame blazing through heather, Router of enemies, his shield stopped their way....

Later in the poem, the poet notes that Madog was "Of a line of kings iron-armed in old time," and that "he loved the poets, the pure idiom of song." 189 From this poem's verses we can see the emphasis on strong warrior-kings, as well as the continued support for court poets even during a period of momentous upheaval for the Welsh.

With the March came Norman aristocratic families to hold claim to the lands. These families were able to marry into the Welsh aristocracy in some cases and solidified relationships across the borders. Gerald of Wales, the prominent writer of the late twelfth century, was of one such family. Gerald's family was the product of Norman lords marrying into the Welsh aristocracy; his grandmother was the famous Welsh princess

${ }^{189}$ Conran, Welsh Verse, 153-154. 
Nest. ${ }^{190}$ The blended families of the March presented grey areas of individual identity that were seen in the mixed cultural state of the March: while there was an AngloNorman population in the new towns, most of the inhabitants were Welsh. ${ }^{191}$ This dynamic also allowed for many of the Welshmen living in the March to gain positions of power within the lordship of the March. The lords of the March, as stated before, had been given absolute autonomy by William I, both to ease the strain on his conquest forces and in order to better defend the rest of his new borders. Because of that decision, the lords of the March were not under the jurisdiction of the monarchy and held positions close to that of a sovereign lord. Lieberman argues that these March estates may have brought Anglo-Norman political institutions into Wales, such as the appointment of the sheriff of Glamorgan in 1102, but not the full Anglo-Norman state; this same sheriff reported to the Norman Lord at Cardiff, rather than the exchequer for England. AngloNorman political customs were thus limited in the March. ${ }^{192}$

\section{Colonial Literacy: Gerald, Walter, and Geoffrey of the March}

In the twelfth century three ecclesiastics who had descended from Marcher families wrote about Wales and the legacy of the British. Gerald of Wales, Walter Map and Geoffrey of Monmouth grew up in areas where both Welsh and English people lived and worked together, giving them first-hand experience with the Welsh, Welsh raiding parties, and Welsh cultural history. Their commentaries on the Welsh were colored by

\footnotetext{
${ }^{190}$ Michael Richter, "Gerald of Wales: A Reassessment on the 750 th Anniversary of His Death," Traditio 29 (1973): 379

${ }^{191}$ Stephenson, Medieval Wales c. 1050-1332, 11.

192 Lieberman, The March of Wales 1067-1300, 81-82.
} 
their experiences. Gerald was half Welsh. Owing to his lineage, Gerald was neither wholly accepted by the Welsh or the Anglo-Normans. Geoffrey and Walter grew up in the March as the children of Norman lords; they had first-hand experience of Welsh raiding and warfare, as well as Welsh customs and stories.

Gerald of Wales wrote his Itinerarium Kambriae (Journey Through Wales) and Descriptio Kambriae (Description of Wales) in 1191, finishing them by $1194 .{ }^{193}$ Journey Through Wales gives a reliable description of the countryside of Wales and some of the people Gerald meets along the way. However, in the midst of his journey, he comes across fantastical creatures, such as the deer-cow and a dog-monkey. ${ }^{194}$ The strange animals stand out to readers, in that they are reminiscent of the strange creatures such as Blemmyes and the dog-headed Cynocephali reported in the travels of John Mandeville. ${ }^{195}$ While The Travels of Sir John Mandeville were written two centuries after the Itinerarium and Descriptio, it is important to look at the style and intention behind the descriptive uses in the text. Gerald did not see the hybrid beasts any more than Mandeville saw the Cynocephali, but their presence promoted a sense of the exotic in their travels. For Gerald, the exotic was the interior of Wales in the twelfth century, a place that seemed to both encourage his Englishness and its anti-Welsh bias and entice his Welshness.

\footnotetext{
${ }^{193}$ Itinerarium Kambriae was started in 1191, and Descriptio Kambriae was written soon afterwards. Richter, "Gerald of Wales: A Reassessment on the 750 th Anniversary of His Death," 382.

${ }^{194}$ Gerald of Wales, Journey Through Wales/The Description of Wales, trans. Thorpe, 199.

195 The author of The Travels of Sir John Mandeville (unknown) does not call the men he describes as Blemmyes, although they are called this in other sources. Instead he says they "are ugly folk without heads, who have eyes in each shoulder..." The Travels of Sir John Mandeville, trans. C.W.R.D. Moseley, (London: Penguin Books, 2005), 134, 137.
} 
Gerald has several agendas in his writing about Wales that give insight into the nature and difficulty of colonialism in Wales. On the one hand, Gerald is steadfastly English. He believes the Welsh lost first Troy and then Britain "because of their sins, and more particularly the wicked and detestable vice of homosexuality," and that although they have since given up that vice, they have not had "any improvement in their morals." 196 He claims the Welsh will not regain their formal glory owing to the fact that they have not done penance for their sins, and instead they are "still sunk in sin and in a deep abyss of every vice - perjury, theft, robbery, rapine, murder, fratricide, adultery, incest, and obstinately ensnared and entangled in wrongdoing, which grows worse as day follows day."197 Gerald uses literature to illustrate the negative side of the Welsh nature. He writes that they "rarely keep their promises," and that they "steal anything they can lay their hands on and live on plunder, theft and robbery, not only from foreigners and people hostile to them, but also from each other." ${ }^{\prime 198}$ In battle, the Welsh warriors will at first appear brave but then "with further resistance they turn their backs, making no attempt at a counter attack, but seeking safety in flight." The Welsh, among their other sins, practice incest: "they have no hesitation or shame in marrying women related to them in the fourth or fifth degree, and sometimes even third cousins," 199 which violated the canon law against consanguineous marriages.

On the other hand, Gerald seems to believe the Welsh have redeeming qualities, which he writes about as well. He describes the Welsh as "light and agile," "fierce rather

\footnotetext{
${ }^{196}$ Gerald of Wales, Journey Through Wales/Description of Wales, trans. Thorpe, 264-265.

197 Ibid., 265.

198 Ibid., 257.

${ }^{199}$ Ibid., 262-263.
} 
than strong, and totally dedicated to the practice of arms." He refers to their love of freedom: "they are passionately devoted to their freedom and to the defense of their country." Gerald describes the Welsh as frugal and above the sin of gluttony or the practice of drunkenness. He also comments on their generosity, stating that "[i]n Wales no one begs. Everyone's home is open to all, for the Welsh generosity and hospitality are the greatest of all virtues." Gerald also discusses their musical ability reverently:

when they come together to make music, the Welsh sing their traditional songs, not in unison, as is done elsewhere, but in parts, in many modes and modulations. When a choir gathers to sing, which happens often in this country, you will hear as many different parts and voices as there are performers, all joining together in the end to produce a single organic harmony and melody in the soft sweetness of B-flat. ${ }^{200}$

These songs are part of what makes the Welsh culturally different, and it is in their music that Gerald finds his appreciation.

The last three chapters of Book II are by far the most telling about Gerald's conflicted views on the Welsh. The translator has added in chapter headings based on the content in each of these chapters: "How the Welsh Can be Conquered," "How the Welsh should be Governed Once they are Conquered," and "How the Welsh Can Best Fight Back and Keep up Their Resistance."201 In the last chapter, "How the Welsh can best Fight Back," Gerald tells his audience of his mixed heritage: "I myself am descended from both peoples. ${ }^{202}$ His mixed heritage is the reason he gives for advising the Welsh on their own defenses against the English. His solution to the Welsh is to "adopt the

\footnotetext{
${ }^{200}$ Ibid., 242.

${ }^{201}$ Ibid., 219.

${ }^{202}$ Ibid., 273.
} 
French way of arming themselves," and "if their princes could come to an agreement and unite to defend their country." ${ }^{203}$ He later compares the Welsh to the English and says that "the English are striving for power, the Welsh for freedom; the English are fighting for material gain, the Welsh to avoid a disaster; the English soldiers are hired mercenaries, the Welsh are defending their homeland." He acknowledges the Welsh-held belief that they are the inheritors of the once great "Kingdom of Britain," which is descended from "Trojan Blood." 204

In his acknowledgement of the Trojan origin story of the Welsh, Gerald's experience with Welsh tales is revealed. Gerald is not the first author to acknowledge the Welsh origin myth. Geoffrey of Monmouth wrote the story of Brutus and his sons making their way from Troy to settle on the island of Britain, to become the descendants of the Welsh. Gerald, however, felt that Geoffrey was a liar. ${ }^{205}$ Gerald's clear opinion of Geoffrey's reliability, paired with his acquiescence of the Trojan origin story for the Britons (Welsh) implies that Gerald would have learned the mythical history of Wales from other sources, most likely from Welsh tales, such as Taliesin. ${ }^{206}$ As he considered

\footnotetext{
${ }^{203}$ Ibid., 272.

${ }^{204}$ Ibid., 274.

${ }^{205}$ In the manuscript, Journey through Wales, Gerald talks about a man named Meilyr, who had gained the ability to see demons and tell when a person was lying, and that he used this skill to find unfaithful monks. Meilyr is said to be so inundated by demons that he would become overwhelmed and Saint John's Gospel would be placed in his lap and immediately dispel the demons. However, "if the Gospel were afterwards removed and the History of the Kings of Britain by Geoffrey of Monmouth were put in its place, just to see what would happen, the demons would alight all over his body, and the book, too, stay there longer than usual and being even more demanding." Gerald of Wales, "Journey through Wales/Description of Wales," 117-118.

${ }^{206}$ Taliesin specifically refers to the Welsh origins as Trojan. The Mabinogi, 173.
} 
himself a serious scholar, Gerald's acknowledgment of this origin story as fact suggests the power and influence Welsh tales had on thinkers and writers outside of Wales.

Gerald's inconsistent view of the Welsh is echoed by Walter Map in The Courtier's Trifles. Map was a colleague of Gerald's, and in fact Gerald had recommended him for the position of bishop in the diocese of St. David's. Like Gerald, Map had grown up as the son of a Marcher lord, and as such had exposure to the Welsh. His writing, unlike Gerald's, seems to focus mainly on relating stories he could use to satirize the court of Henry II with tales that blend aspects of Welsh mythology and mythology from continental Celtic tradition. According to Joshua Byron Smith in Walter Map and the Matter of Britain, "Walter seems to both dislike and idolize the Welsh in his writing. ${ }^{207}$ Smith notes that one of the stories from Courtier's Trifles reads as if he were describing a typical Welsh raider. The character of Cynan the Fearless is likened by Smith to a typical raider, who would have been active in the Marches while Map was a child. As stated earlier, Welsh raids on the March were a concern during the twelfth century and long after. The experience of a Welsh raid would have been a terrifying one, and one that could have inspired Map's unfavorable description of the Welsh. He writes that they do not fear God and are "wholly unfaithful to everybody." 208 Map, like Gerald, is conflicted about his feelings in regards to the Welsh and his place between the Welsh

\footnotetext{
${ }^{207}$ Joshua Byron Smith, Walter Map and the Matter of Britain (Philadelphia: University of Pennsylvania Press, 2017), 12.

${ }^{208}$ Walter Map, De Nugis Curialium, ed. C.N.L Brooke and R.A.B. Mynors (Oxford: Claredon Press, 1983), $145,183$.
} 
and the English: he refers to the Welsh as "my compatriots" ${ }^{209}$ despite depicting them in a negative light. He also shows a fascination with their cultural heritage.

Walter Map used Welsh stories to satirize the court of Henry II. The feelings Map had towards the court of Henry II are made clear in the beginning of his manuscript when he compared the court to Hell and stated, "what form of punishment doth hell provide which is not here multiplied?" ${ }^{210}$ Map was not happy in the court of Henry II, which helps readers to understand his later satire of the court using traditional Welsh storytelling. In Walter Map and the Matter of Britain, Smith analyzes the tale of King Herla. Smith explains that this version of the story is a satire of the court of Henry II, as Walter disapproves of Henry's court. The story's narrator draws a direct connection between Henry II and Herla when he states that the court of king Herla is similar to "their own." Smith explains that Walter disliked Henry's passion for hunting, and Herla met his fate in hunting. Upon his return from the otherworld, Herla was forbidden from dismounting from his horse until after his gift dog dismounted. Herla's constant wandering could also be a jab at the constant movement of Henry II's court, which Smith notes was used as a point of satire. ${ }^{211}$ The fact that Map used elements of traditional Welsh tales as the basis for his satire of the English court demonstrates its power as an avenue of cultural critique.

Geoffrey of Monmouth had already shown the same mixed feelings of fascination and disdain with the Welsh with the Historia Regum Britanniae in the early twelfth century. However, of the three, Geoffrey is the most forgiving - his criticisms are saved

\footnotetext{
${ }^{209}$ Ibid., 183.

${ }^{210}$ Ibid., 1.

${ }^{211}$ Smith, Walter Map and the Matter of Britain, 93-96.
} 
for the end of a long history of the noble Britons (the contemporary Welsh), and mostly speak of how the Britons lost control of the island and were no longer able to rule. Geoffrey writes that "the remnants of the Britons had retreated to Cornwall and Wales," and called them a "slothful race" who allowed themselves to be overrun by the Saxons. ${ }^{212}$ However, from Geoffrey also comes the earliest full version of the Arthurian legend, replete with the Welsh hero Taliesin/Merlin, and of course Arthur. Instead of a war-band leader, Arthur is the rightful king of Britain, and as the story goes, was "taken away to the isle of Avollon to have his wounds tended." ${ }^{213}$ Geoffrey is most well-known for his Arthurian legend and prophesy of Merlin, but most important in this context is his comment concerning "a most ancient book in the speech of the British." ${ }^{214}$ This comment is important because Geoffrey is stating that he is translating a book from Welsh containing their historical narrative. While it is highly likely Geoffrey is making up the existence of the book - it is not referenced in any other contemporary source, and has never been found - the fact that he is claiming to be simply translating the history of the Britons suggests an admiration for the Welsh, or at least their history and cultural heritage. Owing to the similarities of the characters and events, one could deduce that Geoffrey simply read or heard the poems of Aneirin, Taliesin, and tales in the Mabinogi among others, and created a "history" in the same way a Welsh bard would compose his epic tales. The problem with this theory, however, is the tradition in the Middle Ages of

\footnotetext{
${ }^{212}$ Geoffrey of Monmouth, The History of the Kings of Britain, trans. Neil Wright, ed. Michael D. Reeve, (Woodbridge: Boydell Press, 2009), 256-258.

${ }^{213}$ Note the spelling of Avalon is different than traditional spelling. The Latin text names Avalon "insulam Avallonis" and translator Neil Wright chose to keep the double 'l' in his translation . Ibid., 252, 253.

${ }^{214}$ The Latin quote is "Britannici sermonis librum uetustissimum." Ibid., 4.
} 
citing sources in order to give one's book an authoritative air, especially if Geoffrey was writing his own stories based on Welsh stories. According to Hans-Werner Goetz, "since authority was regarded as being of much greater importance than one's own originality, and since the past had much more weight than the present, [...], medieval historiography was to a great extent compilation from older works and other information." ${ }^{215}$ Whether Geoffrey is using an ancient source to give his own manuscript authority, or simply transmitting ancient Welsh stories, it is clear that he held the history of the Welsh (Britons) as they told it through poems and tales in high enough regard to write a history for them that he considered noble and ancient.

The relevance of these three ecclesiastic writers is simply that they recorded Wales and the Welsh having experienced living as their neighbors. Their narratives and insights give the view of those who had both respect for and fear of the Welsh and could speak from first-hand experience of what the Welsh were like to those living in the March. While each author notes their brutality and comparatively wild behavior, each author also shows his admiration in the transmission of their stories. The fact that elements and heroes from Welsh literature are present tells the reader that there was meaning to these stories, and that they were still relevant. They are filled with magic and valor and, in Map's case, proved a useful resource with which to satirize the monarchy of England. The fact that their writing has been preserved and celebrated for nearly a millennium after their initial publication shows the resonance their words and the styles

\footnotetext{
${ }^{215}$ Hans-Werner Goetz, "The 'Methodology' of Medieval Chroniclers," in Chronicon Medieval Narrative Sources: A Chronological Guide with Introductory Essays, ed. János M. Bak and Ivan Jurković (Turnhout: Brepols, 2013), 30-31.
} 
they copied had on Europe. For example, Geoffrey's tales of Cordelia and King Lear were reimagined by Shakespeare in his play King Lear, and to this day new versions of Geoffrey's tale of King Arthur, Merlin, and his knights of the Round Table still occupy a place in popular media.

The incursions of the Anglo-Normans into Wales through the construction of Marches was slow, calculated and not completely successful. The Welsh fought back against the taking of Wales, with the encouragement of the poets via poems and tales involving strong warrior kings and their heroic exploits. By the same token, the Welsh and the people living in the March began to exchange customs and information, creating a cultural give and take, resulting in the disbursement of Welsh story-telling and ideas throughout Europe. Geoffrey's Arthur story, based on Welsh poetry, blossomed into a phenomenon that was translated into French and made into a Romance. The Welsh longbow made its debut against the Anglo-Norman military, who then used it at the battle of Agincourt during the Hundred Years' War. The Norman tradition of hostage-taking, castle sieges and ransoms took the place of plunder, devastation of land, castration, and blinding in Welsh warfare. Behind the fight for Wales, lay an undercurrent of poets, who encouraged the princes to continue to fight, with stories of brave warriors who gained immortality through poetry and tales documenting their deeds. Not only did these tales encourage the princes to fight for Wales, but they also inspired men such as Walter Map and Geoffrey of Monmouth to create their own tales of noble warrior-kings. During the three centuries of slow conquest, the Welsh and the Anglo-Norman lords exchanged ideas and learned from each other. 
The exchange of ideas, culture, and military technology between the two cultures in the Marches all but disappeared with the death of Llywelyn ap Gryffud in 1283. Wales officially became a part of England in 1284 during the reign of Edward I. The relationship between Wales and England has remained complicated since; Wales continued to maintain some sovereignty while also resolutely being a part of England. They held their own parliament and law codes, in Welsh, until the Laws in Wales Acts of 1535 and 1542, when Henry VIII disbanded the Welsh political system, had representatives for Wales in the English parliament, and insisted on English as the official language of Wales. Despite Edward's assertion of dominance over Wales, the Welsh continued to rebel against the English for centuries. Stephenson notes that there were major rebellions, such as the 1314 rebellion in Glamorgan after the death of the last Clare lord, followed by the uprising of Llywelyn Bren, also of Glamorgan, in $1316 .{ }^{216}$ These rebellions were the direct result of the oppressions of the Welsh by the Normans in the years following 1284. Despite these rebellions, and the rebellion of Owain Glyn Dŵr at the turn of the fifteenth century, Wales slowly settled into a working relationship with England.

${ }^{216}$ Stephenson, Medieval Wales: c.1050-1332, 149. 


\section{Chapter 5}

\section{Conclusions}

The High Middle Ages saw changes throughout Europe, especially in face of Norman conquests and colonization. The Normans made their way to Anglo-Saxon England and defeated Harold at the Battle of Hastings in 1066, and then proceeded to establish themselves over the entirety of the British Isles. By 1086, William the Conqueror had moved west into Wales, and the first March was established in order to secure the western border of his new kingdom. To William this was a strategic move in the interest of England; to the Welsh, this was an unacceptable incursion into their independent land. The negative views the Welsh had of Anglo-Norman colonization can be observed in their contemporary literature.

The ideas of nationhood, imperialism, and colonialism that were presented in this paper are different from those of the early modern period. As touched on by many other scholars, such as Robert Bartlett and R.R. Davies, there was no concept of nationhood as understood today. Belonging was typically fostered on a much smaller scale; it encompassed the lord, his vassals, and the people who lived and worked on the immediate surrounding land. European colonialism in the High Middle Ages was the process of groups moving outward from central Europe to expand the territory they already controlled, rather than a push to dominate resources as well as people. While the Normans in Wales may be called colonists, the move into Wales was not centrally driven or controlled. 
Before the Norman incursion into Wales, the Welsh had been considered independent from the Anglo-Saxons, while at the same time experiencing attempts (some successful) by the Anglo-Saxons for control over small regions in the eastern part of Wales. However, Wales had mostly been and remained independent from the rest of the island. Within its borders, the princes of Powys, Gwynedd, Deheubarth, Dyfed, and Glamorgan fought with each other for supremacy. The fighting was ultimately between cousins, brothers, nephews and even sons, or in response to frequent raids by the Irish, Scandinavians and Flemings. The ability to rule Wales in its entirety as a single entity was next to impossible, although it was attempted from time to time by men such as Hywel Dda, Llywelyn ap Iowerth, and Llywelyn ap Gruffudd. Inter-Welsh violence and competition for and lack of resources was compounded by the addition of Norman lords looking to expand their holdings in Wales. However, despite the internal and external difficulties for the Welsh, they shared a common language, history, poetry, and law.

The bards and story-tellers of Wales in the High Middle Ages were a part of a long-standing, long-honored tradition. Poets were held in high esteem in courts as the bearers of history and as such enjoyed power within the courts. This is demonstrated by the poem Taliesin, in which the poet Taliesin forces King Maelgwn to let his master Elphin free. Taliesin tells them that he is Merlin and has been around since Adam and Eve. This story is an extension on Gwion Bach, the tale of how the knowledge of the word and poetry was stolen by a servant. The real Taliesin, a sixth-century poet, was a contemporary of Aneirin, and they both wrote of the valor of the Britons (later Welsh) against the invading Angles and Saxons in northern Briton. These poems are the earliest 
on record and show the long-standing tradition of warrior-culture through the poetry. The poets of the High Middle Ages later built on these traditions and carried on the stories of the Welsh mythic past. This tradition of stories and poems resonated with the Marcher lords and was subsequently shared. The story of Arthur and his war-band and Taliesin/Merlin was changed by Geoffrey of Monmouth to become a wide-spread, wellread story; one which would resonate throughout the Middle Ages and even today. Walter Map adapted stories of kings disappearing into the Otherworld for his intended aristocratic and royal English audience.

The Welsh princes, their retinues and their poets garnered the attention of the Normans in several ways. they stood out as "barbaric" for their brutal warfare; the princes never were able to come together to form a single united group, and their poetry, song and literature were enchanting. The Normans moved into the region to secure their borders, but the process was slow and cautious. The Marches, independent from both the Anglo-Normans and the Welsh, flourished with a mix of Welsh and Anglo-Norman culture, becoming what historian David Stephenson referred to as a cultural conduit. ${ }^{217}$ The Marches expanded throughout the Middle Ages, and though the Welsh fought against their expansion, by the end of the thirteenth century, Wales was a part of England.

Poetry, the Norman colonization via the March, and the internal feuding between princes in Wales together led to the ending of Wales as an independent region. The Normans in the High Middle Ages were a strong colonizing force, known for their ability in battle and strategic castle-building. When William the Conqueror became the king of

${ }^{217}$ Stephenson, Medieval Wales c. 1050 -1332, 76. 
England, he created the March in order to add to the defense of his border, and his descendants continued the expansion by giving land in the expanding March over to the Anglo-Norman aristocracy.

It can be said that the success of the Anglo-Normans in Wales was owed to the near constant state of warfare between the Welsh princes. The raiding and destruction and lack of a strong, cohesive political structure helped prevent the Welsh from organizing under one ruler. Without the strength of a cohesive Welsh army under a single king, the Welsh were unable to efficiently repel the Anglo-Norman invaders. The Welsh did hold onto some independence for a considerable amount of time - two centuries - before becoming a part of England. This is likely due to the resiliency of the Welsh culture and desire for continued sovereignty.

Welsh literature from the Middle Ages reflects the attitudes of the Welsh towards the Anglo-Norman colonization, while also emphasizing long-standing Welsh culture and traditions. These poems and tales worked with and against the Welsh in their long fight to maintain independence. Welsh poets used the long-standing tradition of poetry to encourage princes to fight against the Anglo-Normans by praising princes who fought against the Anglo-Normans. Old stories and songs were written down in the High Middle Ages, such as the poems of Taliesin and Aneirin, praising the Britons (Welsh) in their fight against the invading Saxons and Angles in the sixth century. These poems and poets created the underlying morals of the warrior culture, encouraging the ideals of the strong, warrior-king with a war-band, ready to fight and to pillage his neighbors and enemies. The same poets who encouraged the Welsh to fight for their land were also encouraging 
the Welsh princes to fight each other. In this way, the poets both exacerbated the problem of Anglo-Norman invasion and encouraged the Welsh to fight against it. The literary culture of Wales was a double-edged sword for the Welsh but was only a part of the equation. An investigation into these three aspects during the creation of the March Anglo-Norman expansion into Wales shows that poetry, civil warfare, and outside incursions were all three major contributors in the loss of Welsh independence. 


\section{References}

\section{Primary Sources}

Anglo-Saxon Chronicles: The History of the Anglo-Saxons. Translated by Rev. James Ingram and J.A. Giles. London, 1823.

Brut y Tywysogion. Translated by Rev. John Williams Ab Ithel. London: Longman, Green, Longman and Roberts, 1860.

Domesday Book. Edited by Dr. Ann Williams, Professor G.H. Martin. London: Penguin Press, 1992.

The Earliest Welsh Poetry. Translated by Joseph P. Clancy. London: St. Martin's Press, 1970.

Geoffrey of Monmouth. The History of the Kings of Britain. Translated by Neil Wright, ed. Michael D. Reeve. Woodbridge: Boydell Press, 2009.

Gerald of Wales. The Journey Through Wales/The Description of Wales. Translated by Lewis Thorpe. London: Penguin Books, 1978.

Gerald of Wales. The History and Topography of Ireland. Translated by John F. O’Meara. London: Penguin Books, 1951.

Giraldus Cambrensis. Expugnatio Hibernica: The Conquest of Ireland. Translated by A.B. Scott and F.X. Martin. Dublin: Royal Irish Academy, 1978.

The Mabinogi and Other Medieval Welsh Tales. Translated by Patrick K. Ford. Berkeley: University of California Press, 2008.

Medieval England 1000 -1500: A Reader. Edited by Emilie Amt. New York: University of Toronto Press, 2008.

The Travels of Sir John Mandeville. Translated by C.W.R.D. Moseley. London: Penguin Books, 2005), 134, 137.

Walter Map. De Nugis Curialium. Edited by C.N.L. Brooke and R.A.B. Mynors. Oxford: Clarendon Press, 1983.

Welsh Court Poems. Edited by Rhian M. Andrews. Cardiff: University of Wales Press, 2007.

Welsh Verse. Edited by Tony Conran. Bridgend: Wales Poetry Press, 1986. 


\section{Secondary Sources}

Andrews, Rhian M. "Introduction." In Welsh Court Poems. Cardiff: University of Wales Press, 2007.

Bartlett, Robert. England Under the Norman and Angevin Kings: 1075-1225. Oxford: Clarendon Press, 2000.

Bartlett, Robert. Gerald of Wales: A Voice of the Middle Ages. Stroud: The History Press, 2013.

Bartlett, Robert. The Making of Europe: Conquest, Colonization and Cultural Change 950-1350. Princeton: Princeton University Press, 1993.

Black, Jeremy. Convergence or Divergence: Britain and the Continent. New York: St. Martin's Press, 1994.

Breeze, Andrew. "Warlords and Diplomats in the Four Branches of the Mabinogi." In War and Peace: Critical Issues in European Societies and Literature 800-1800. Edited by Albrecht Classen and Nadia Margolis. 155-169. Berlin: De Gruyter, 2011. ProQuest E-book Central.

Cessford, C. "Northern England and the Gododdin Poem." Northern History 33, no. 1 (1997): 218-222.

Christie, Neil. The Fall of the Western Roman Empire. New York: Bloomsbury Academic, 2011.

Cichon, Michael. "Eros and Error: Gross Sexual Transgression in the Fourth Branch of the Mabinogi." In The Erotic in the Literature of Medieval Britain. Edited by Amanda Hopkins and Cory James Rushton. 105-115. Cambridge: D.S. Brewer, 2007.

Conran, Tony. "Mabinogion.” In Welsh Verse. Edited by Tony Conran. 135-136. Bridgend: Wales Poetry Press, 1986.

Davies, Morgan T. "Dafydd ap Gwilym and the Shadow of Colonialism." In Medieval Celtic Literature and Society. Edited by Helen Fulton. 248-274. Dublin: Four Courts Press, 2005.

Davies, R.R. The Age of Conquest: Wales, 1063-1415. Oxford: Oxford University Press, 2000. 
Davies, R.R. "Law and National Identity in Medieval Wales." In Welsh Society and Nationhood: Historical Essays Presented to Glanmor Williams. Edited by R.R. Davies, Ralph A. Griffiths, Ieuan Gwynedd Jones, and Kenneth O. Morgan. 5169. Cardiff: University of Wales Press, 1984.

Davies, R.R., and Geraint H. Jenkins, eds. From Medieval to Modern Wales: Historical Essays in Honour of Kenneth O. Morgan and Ralph A. Griffiths. Edited by R.R. Davies, Ralph A. Griffiths, Ieuan Gwynedd Jones, and Kenneth O. Morgan. Cardiff: University of Wales Press, 2004.

Freer, Esther, and Jones, Nerys Ann. "A Poet and his Patrons: The Early Career of Llywarch Brydydd y Moch." In Medieval Celtic Literature and Society. Edited by Helen Fulton. Dublin: Four Courts Press, 2005.

Foley, Chris. "Reading fifth-century British history." Journal of the Australian Early Medieval Association 6 (2010): 75+. Gale Academic OneFile (accessed February 7, 2020). https://link-gale-com.proxy.lib.pdx.edu/apps/doc/A249135957/AONE?u=s11857 $84 \&$ sid $=$ AONE $\&$ xid $=2 \mathrm{~d} 58278 \mathrm{~d}$.

Fulton, Helen. "The Mabinogi and the Education of Princes in Medieval Wales." In Medieval Celtic Literature and Society. Edited by Helen Fulton. 230-247. Dublin: Four Courts Press, 2005.

Fulton, Helen, ed. Urban Culture in Medieval Wales. Cardiff: University of Wales Press, 2012.

Griffiths, Ralph A. "Medieval Severnside: The Welsh Connection." In Welsh Society and Nationhood: Historical Essays Presented to Glanmor Williams. Edited by R.R. Davies, Ralph A. Griffiths, Ieuan Gwynedd Jones, and Kenneth O. Morgan. 7089. Cardiff: University of Wales Press, 1984.

Goetz, Hans-Werner. “The 'Methodology' of Medieval Chroniclers.” In Chronicon: Medieval Narrative Sources: A Chronological Guide with Introductory Essays. Edited by János M. Bak and Ivan Jurković. 25-33. Turnhout: Brepols, 2013.

Henley, Georgia, and A. Joseph McMullen, eds. Gerald of Wales: New Perspectives on a Medieval Writer and Critic. Cardiff: University of Wales Press, 2018.

Higham, Nick, ed. Britons in Anglo-Saxon England. Woodbridge: The Boydell Press, 2007.

Jackson, Kenneth. The Gododdin: the Oldest Scottish Poem. Edinburgh: Edinburgh University Press, 1969. 
Koch, John. "Why was Welsh Literature First Written Down?" In Medieval Celtic Literature and Society. Edited by Helen Fulton. 15-31. Dublin: Four Courts Press, 2005.

Lieberman, Max. The March of Wales 1067-1300: A Borderland of Medieval Britain. Cardiff: University of Wales Press, 2019.

Maund, Kari. The Welsh Kings: Warriors, Warlords and Princes. Stroud: Tempus, 2006.

Richter, Michael. "Gerald of Wales: A Reassessment on the $750^{\text {th }}$ Anniversary of His Death.” Traditio 29 (1973): 379-390.

Runcie, Charlotte. "Dylan Thomas: Best Poems and Quotes - which one is your favorite?" The Telegraph. Accessed 1/22/20. https://www.telegraph.co.uk/culture/books/11186744/Dylan-Thomas-best-poemsquotes.html

Smith, Joshua Byron. Walter Map and the Matter of Britain. Philadelphia: University of Pennsylvania Press, 2017.

Stacey, Robin Chapman. "Law and Literature in medieval Ireland and Wales." In Medieval Celtic Literature and Society. Edited by Helen Fulton. 65-82. Dublin: Four Courts Press, 2005.

Stephenson, David. Medieval Wales c. 1050-1332: Centuries of Ambiguity. Cardiff: University of Wales Press, 2019.

Tenorio-Trillo, Mauricio. Clio's Laws on History and Language. Translated by Mary Ellen Fieweger. Austin: University of Texas Press, 2019.

Walker, David. "Cultural Survival in an Age of Conquest." In Welsh Society and Nationhood: Historical Essays Presented to Glanmor Williams. Edited R.R. Davies, Ralph A. Griffiths, Ieuan Gwynedd Jones, and Kenneth O. Morgan. 3550. Cardiff: University of Wales Press, 1984.

Williams, J.E. Caerwyn. "Gildas, Maelgwn and the Bards." In Welsh Society and Nationhood: Historical Essays Presented to Glanmor Williams. Edited by R.R. Davies, Ralph A. Griffiths, Ieuan Gwynedd Jones, and Kenneth O. Morgan. 1934. Cardiff: University of Wales Press, 1984. 


\section{Tertiary Sources}

"Aneirin." In Merriam Webster's Encyclopedia of Literature. Springfield, MA: MerriamWebster, 1995. Gale Academic OneFile (accessed February 9, 2020). https://linkgale-

com.proxy.lib.pdx.edu/apps/doc/A148914756/AONE?u=s1185784\&sid=AONE\& $\underline{x i d=c 3 b 7 d 94 d .}$

Kohn, Margaret and Reddy, Kavita. "Colonialism." The Stanford Encyclopedia of Philosophy (Fall 2017 Edition), Edward N. Zalta (ed.), URL = <https://plato.stanford.edu/archives/fall2017/entries/colonialism/>.

National Library of Wales. "Book of Aneirin.” Accessed April 18, 2020. https://www.library.wales/discover/digital-gallery/manuscripts/the-middleages/book-of-aneirin $\#$ ? $\mathrm{c}=\& \mathrm{~m}=\& \mathrm{~s}=\& \mathrm{cv}=\& \mathrm{xywh}=-99 \% 2 \mathrm{C}-$ 478\%2C4453\%2C 3786

National Library of Wales. "Brut y Tywysogion.” Accessed May 29, 2020. https://www.library.wales/discover/digital-gallery/manuscripts/the-middleages/chronicle-of-the-princes $\#$ ? $\mathrm{c}=\& \mathrm{~m}=\& \mathrm{~s}=\& \mathrm{cv}=\& \mathrm{xywh}=-642 \% 2 \mathrm{C}-$ 1\%2C3273\%2C2784

Llywodraeth Cymru/Welsh Government. "Historical Timeline of Welsh Law." Law Wales. Helping you Understand Welsh Law. Accessed April 26, 2020. https://law.gov.wales/constitution-government/how-welsh-laws-made/timelinewelsh-law/?lang=en\#/constitution-government/how-welsh-laws-made/timelinewelsh-law/?tab=overview\&lang=en 
Appendix A: Maps of Wales

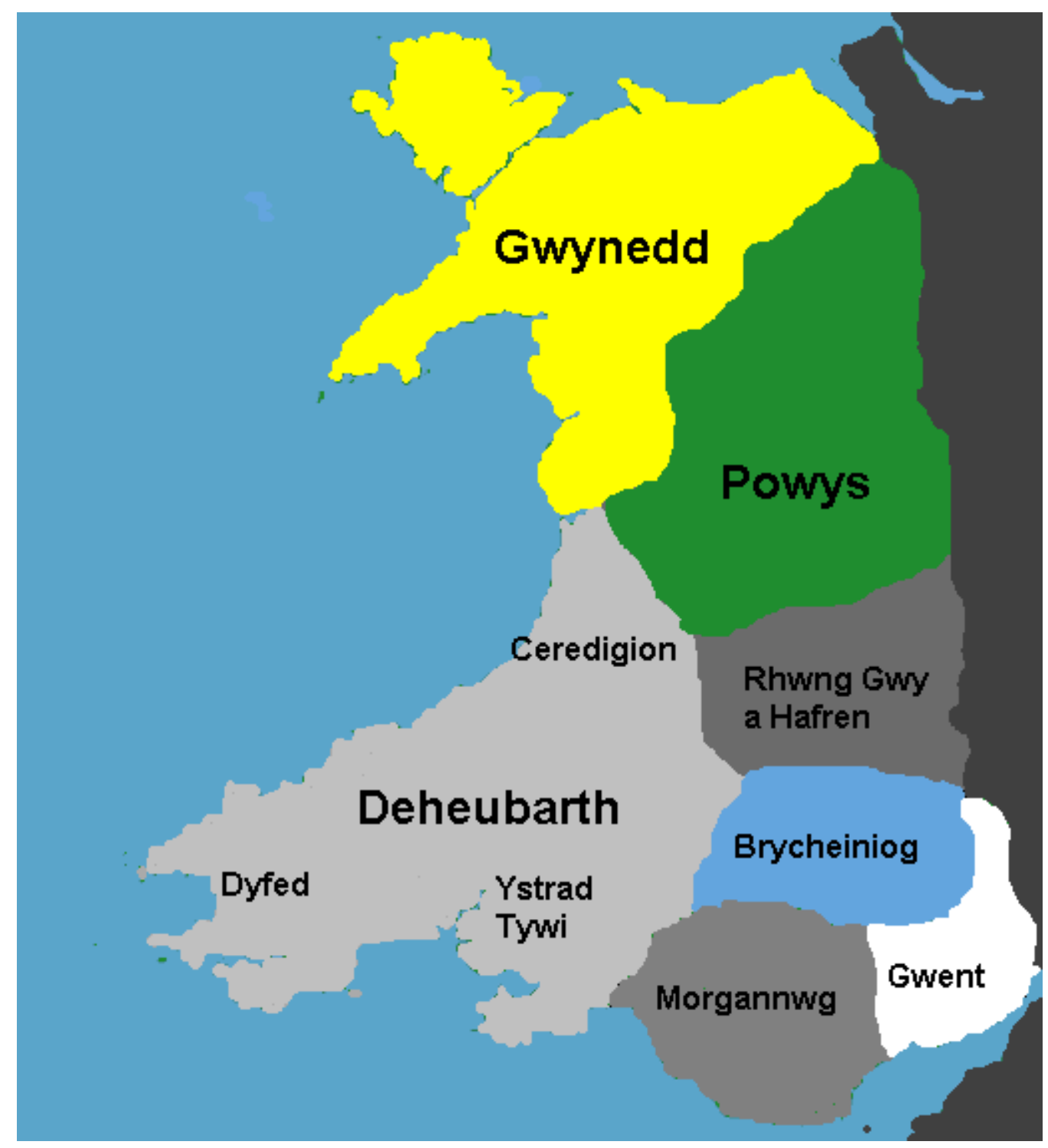

Wales $1063-1081$

(public domain) Public Domain,

https://commons. wikimedia.org/w/index.php?curid=1012987 


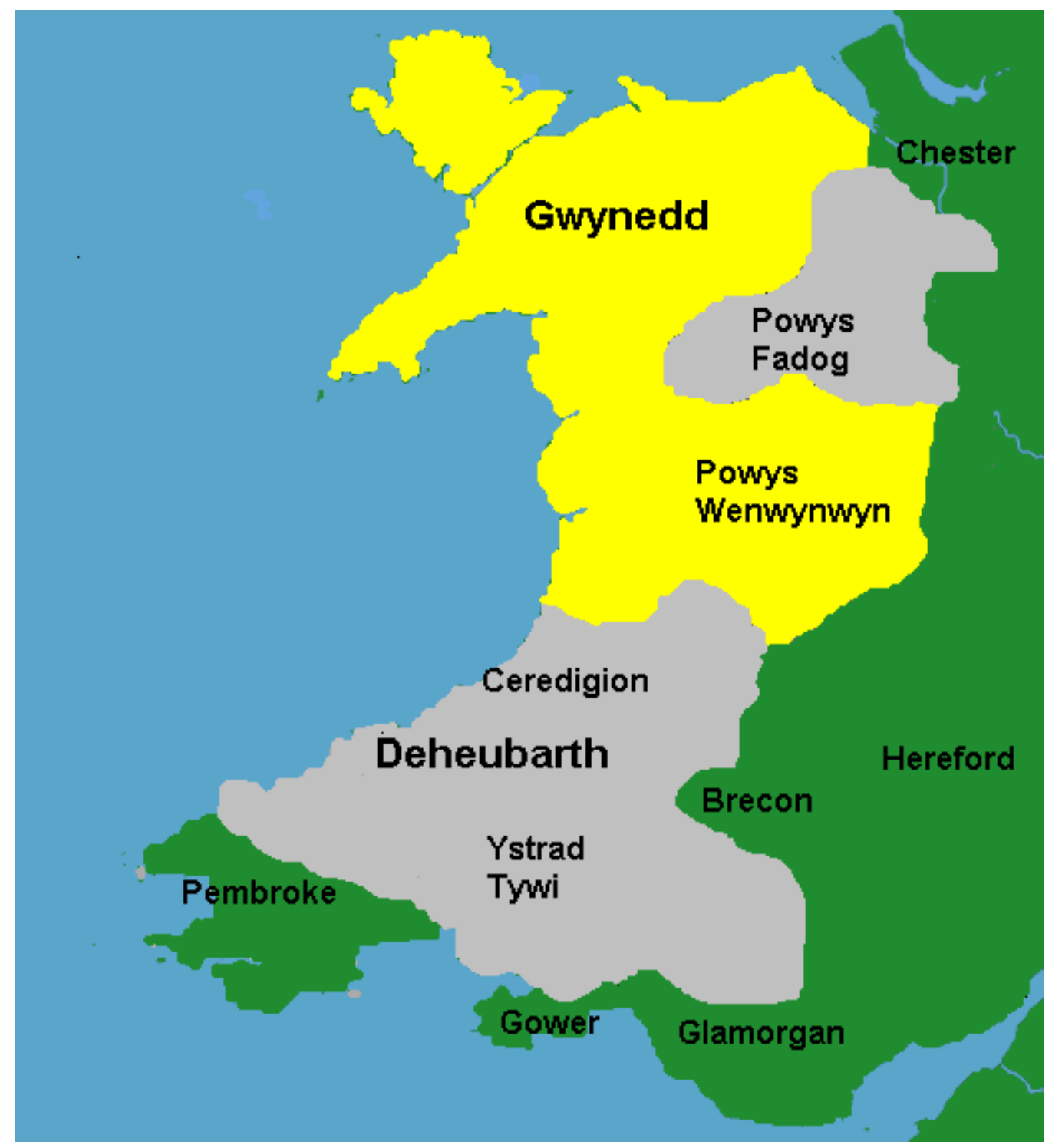

Wales 1217

wiki commons 


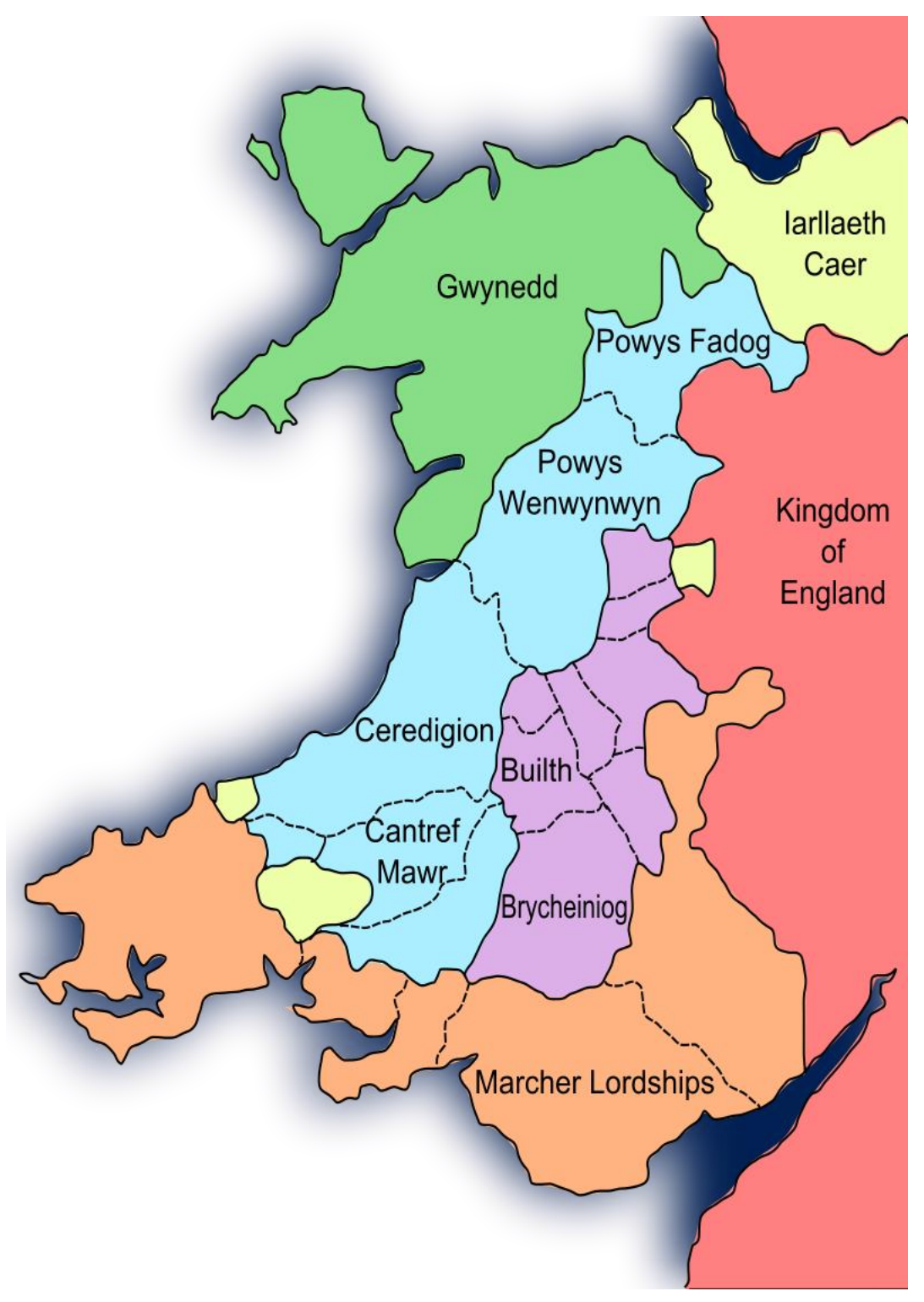

Wales 1267 - 1277

By Alex D - Own work, CC BY-SA 3.0, https://commons. wikimedia.org/w/index.php?curid=5537020 


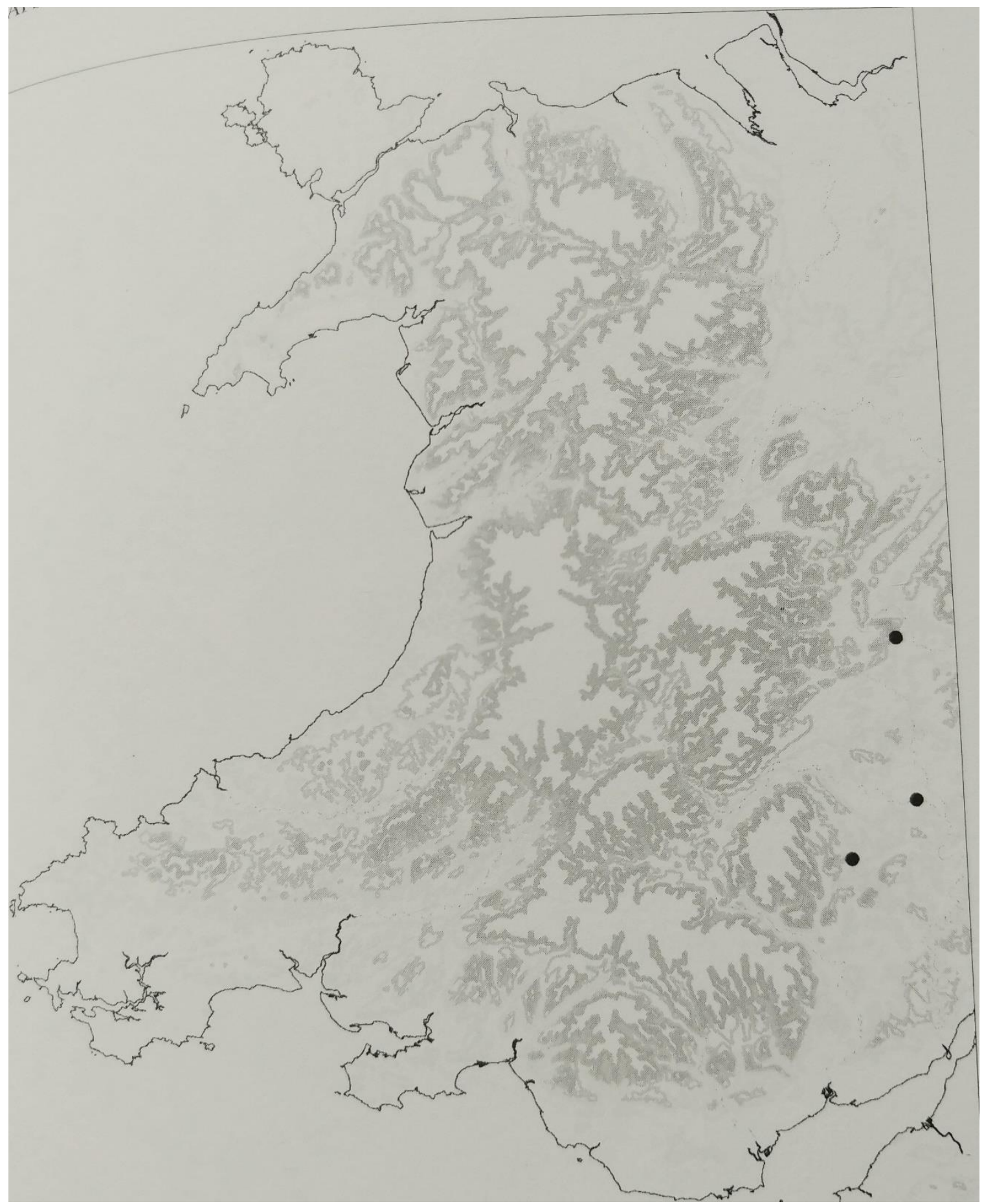

Castles in Wales and the March, $1066^{218}$

${ }^{218}$ Lieberman, The March of Wales, 135. 


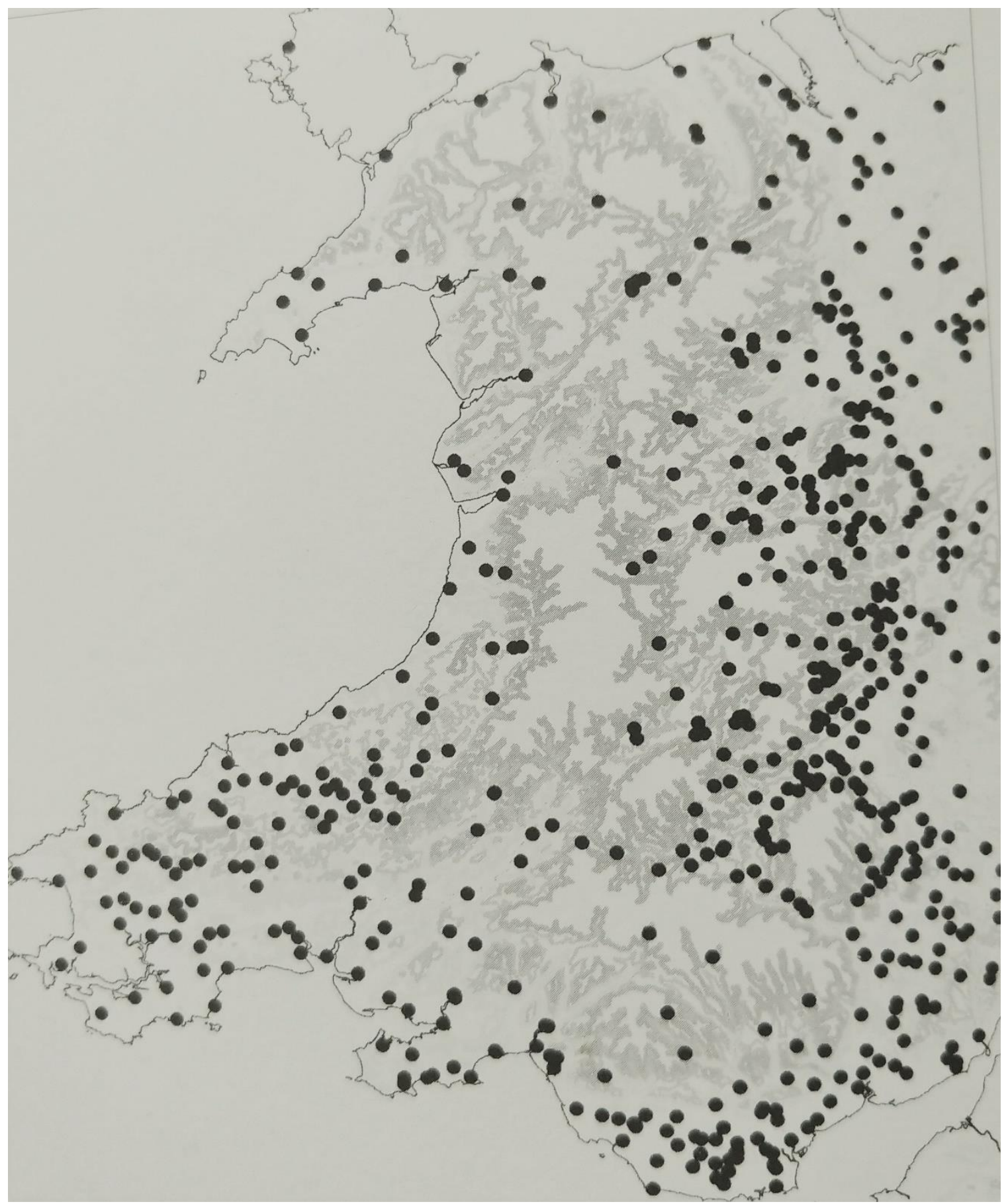

Castles in Wales and the March, $1215^{219}$

${ }^{219}$ Ibid., 136. 


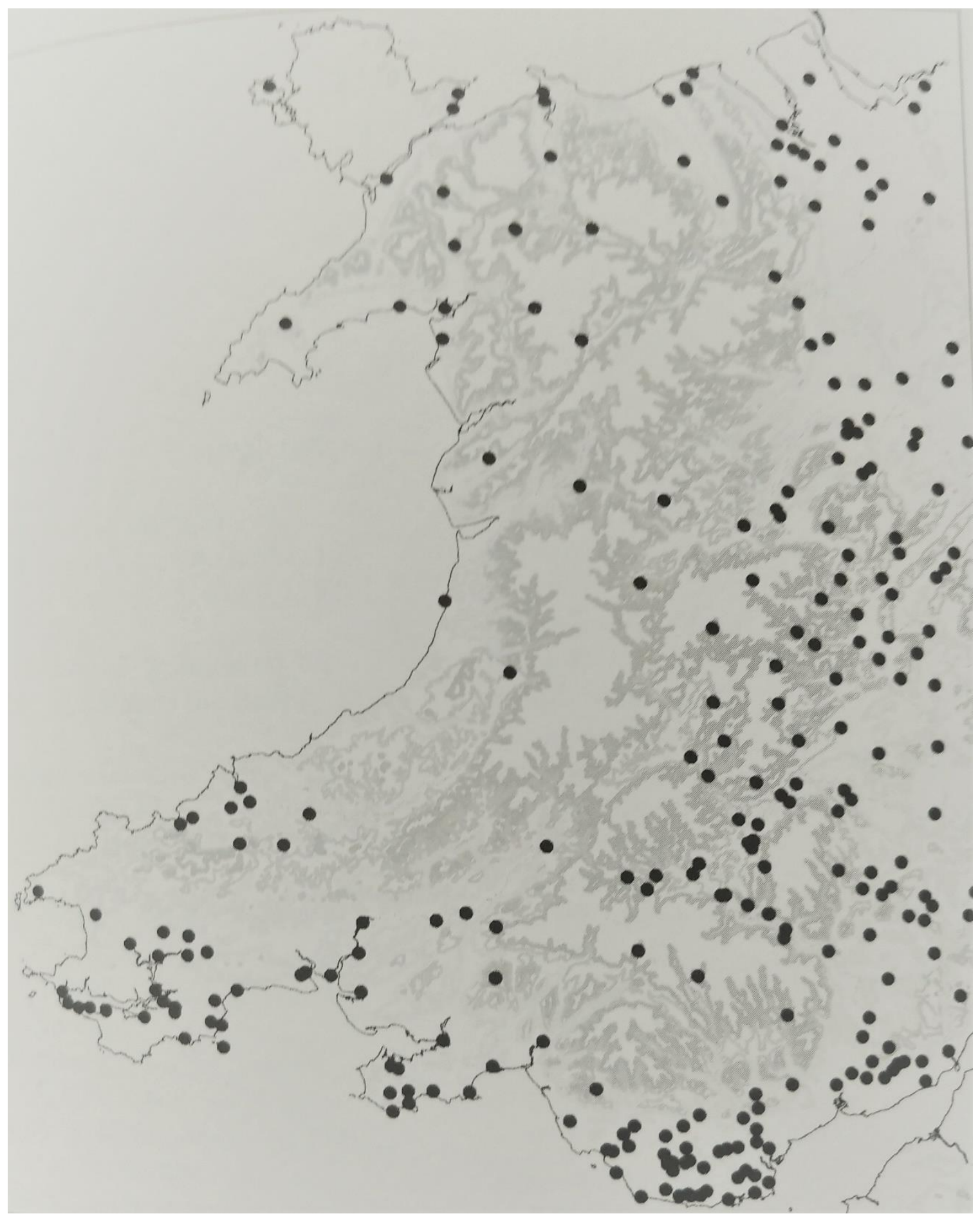

Castles of Wales and the March, $1300^{220}$

${ }^{220}$ Ibid., 137. 


\section{Appendix B: Timeline of Historic Events}

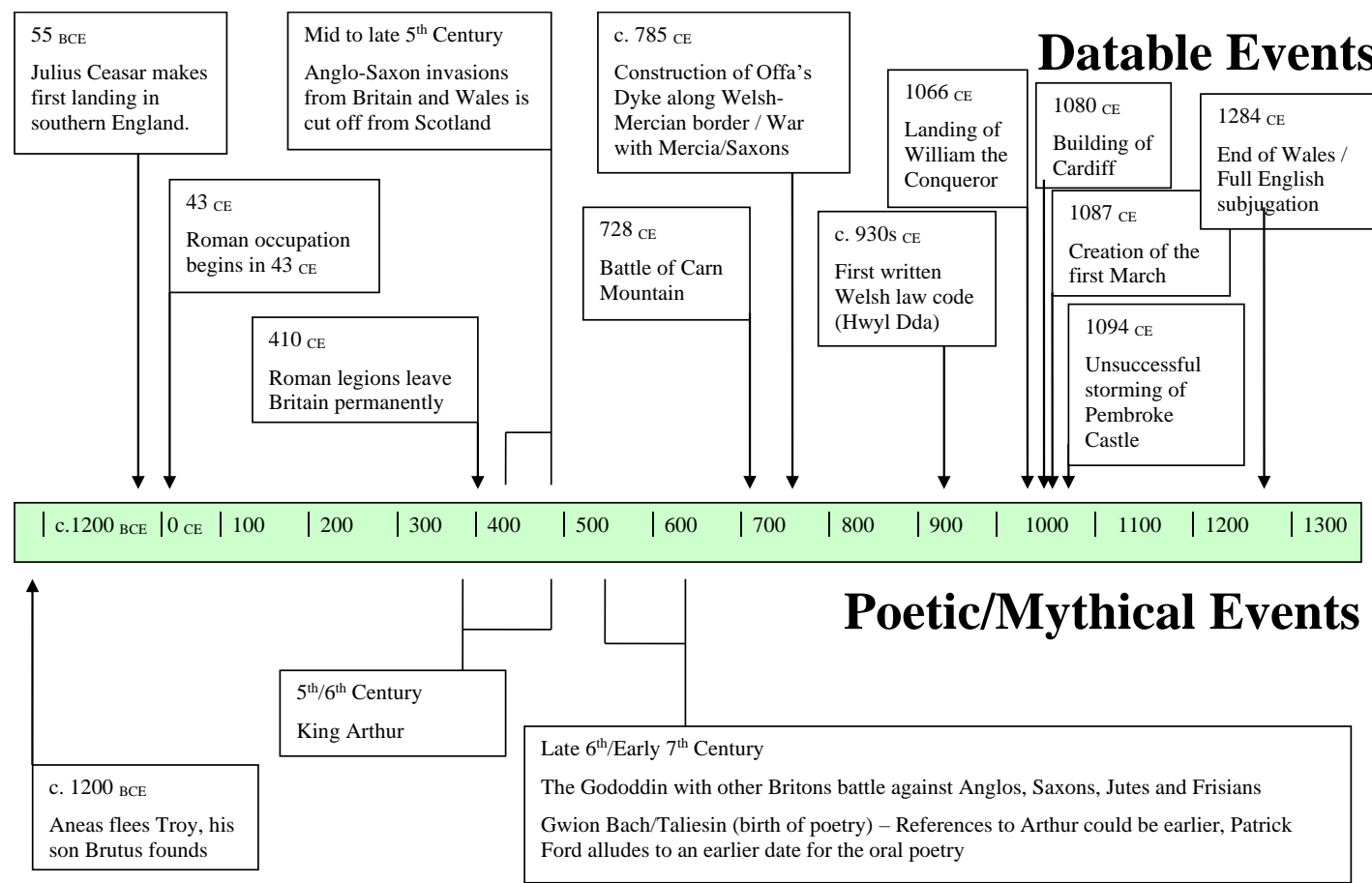




\section{Appendix C: Table of Texts}

\begin{tabular}{|c|c|c|c|}
\hline Title & Author & $\begin{array}{l}\text { Date of the oldest } \\
\text { surviving manuscript }\end{array}$ & $\begin{array}{l}\text { Oral tradition or } \\
\text { older manuscript } \\
\text { - proposed dates }\end{array}$ \\
\hline The Gododdin & Aneirin & c. $1250-1300_{\mathrm{CE}}$ & $\begin{array}{l}\text { One older copy } \\
\text { known to have } \\
\text { existed from the } 8^{\text {th }} \\
\text { century. Possible } \\
\text { previous oral } \\
\text { tradition or written } \\
\text { copies. }\end{array}$ \\
\hline $\begin{array}{l}\text { The Four Branches of the } \\
\text { Mabinogi }\end{array}$ & Unknown & $\begin{array}{l}\text { 1300-1324: White Book } \\
\text { of Rhydderch } \\
\text { 1375-1425: Red Book of } \\
\text { Hergest }\end{array}$ & $\begin{array}{l}\text { The oral and written } \\
\text { traditions are } \\
\text { believed to be older, } \\
\text { and fragments of } \\
\text { these stories are } \\
\text { found in older } \\
\text { manuscripts. }\end{array}$ \\
\hline Gwion Bach/Taliesin & Unknown & $16^{\text {th }}$ century & $\begin{array}{l}\text { Known to be much } \\
\text { older. }\end{array}$ \\
\hline The Brut y Tywysogion & Unknown & c. 1330 & $\begin{array}{l}\text { Believed to be } \\
\text { comprised of many } \\
\text { different chronicles } \\
\text { from monasteries } \\
\text { throughout Wales }\end{array}$ \\
\hline Historia Regum Britannia & $\begin{array}{l}\text { Geoffrey of } \\
\text { Monmouth }\end{array}$ & c. $1250-1300$ & $\begin{array}{l}\text { Earliest manuscript } \\
\text { was written between } \\
1123-1139\end{array}$ \\
\hline $\begin{array}{l}\text { Journey Through Wales/ } \\
\text { Description of Wales }\end{array}$ & Gerald of Wales & $13^{\text {th }}$ century & $\begin{array}{l}\text { c. } 1191-1194, \\
\text { dedicated to Henry II } \\
\text { in } 1215\end{array}$ \\
\hline De nugis curialus & Walter Map & Early $14^{\text {th }}$ century & Late $12^{\text {th }}$ century \\
\hline $\begin{array}{l}\text { Poetry of the Princes } \\
\text { (medieval court poetry) }\end{array}$ & $\begin{array}{l}\text { Miscellaneous ( } 60 \\
\text { poets over } 270 \\
\text { poems) }\end{array}$ & c. $1282-1350$ & $\begin{array}{l}\text { This type of poetry } \\
\text { refers specifically to } \\
\text { poems written about } \\
\text { princes between } 1100 \\
-1285 \text {. }\end{array}$ \\
\hline $\begin{array}{l}\text { Armes Prydain/Prophesy of } \\
\text { Britain }\end{array}$ & Unknown & c. $1300-1325$ & $\begin{array}{l}\text { Thought to be } \\
\text { originally written } \\
\text { during the } 10^{\text {th }} \\
\text { century }\end{array}$ \\
\hline
\end{tabular}

